\title{
Structural and functional divergence of gonadotropin- inhibitory hormone from jawless fish to mammals
}

\section{Satoshi Ogawa and Ishwar S. Parhar*}

Brain Research Institute, Jeffrey Cheah School of Medicine and Health Sciences, Monash University Malaysia, Petaling Jaya, Malaysia

Edited by:

Karine Rousseau, Muséum National

d'Histoire Naturelle, France

\section{Reviewed by:}

Stacia A. Sower, University of New Hampshire, USA

Gustavo M. Somoza, Instituto de

Investigaciones

Biotecnologicas-Instituto Tecnologico

de Chascomus, Argentina

Francisco Gaytán, University of

Cordoba, Spain

*Correspondence:

Ishwar S. Parhar, Brain Research Institute, Jeffrey Cheah School of

Medicine and Health Sciences,

Monash University Malaysia, Petaling

Jaya, Selangor 47500, Malaysia

e-mail: ishwar@monash.edu
Gonadotropin-inhibitory hormone $(\mathrm{GnlH})$ was discovered as a novel hypothalamic peptide that inhibits gonadotropin release in the quail. The presence of $\mathrm{GnIH}$-homologous peptides and its receptors (GnlHRs) have been demonstrated in various vertebrate species including teleosts, suggesting that the GnlH-GnIHR family is evolutionarily conserved. In avian and mammalian brain, $\mathrm{GnIH}$ neurons are localized in the hypothalamic nuclei and their neural projections are widely distributed. $\mathrm{GnIH}$ acts on the pituitary and gonadotropin-releasing hormone neurons to inhibit reproductive functions by decreasing gonadotropin release and synthesis. In addition, GnlH-GnlHR signaling is regulated by various factors, such as environmental cues and stress. However, the function of fish $\mathrm{GnlH}$ orthologs remains inconclusive because the physiological properties of fish $\mathrm{GnIH}$ peptides are debatable. This review summarizes the current research progress in $\mathrm{GnlH}-\mathrm{Gn} l \mathrm{HR}$ signaling and their physiological functions in vertebrates with special emphasis on non-mammalian vertebrate species.

Keywords: LPXRFa, GnRH, reproduction, teleosts, gonadotropin

\section{INTRODUCTION: DISCOVERY OF GnIH}

When the reproductive axis is triggered, gonadotropin-releasing hormone $(\mathrm{GnRH})$, a neuropeptide involved in regulating vertebrate reproduction, is released from the hypothalamus. The released GnRH then enters into the anterior pituitary gland and triggers the release of gonadotropins: luteinizing hormone (LH) and follicle-stimulating hormone (FSH) $(1,2)$. These gonadotropins act on the gonads to stimulate the synthesis and release of gonadal steroids (3). Kisspeptin, the peptide product of KISS1/Kiss 1 gene and its cognate receptor (GPR54 = kisspeptin receptor) has been well recognized as a potent regulator of $\mathrm{GnRH}$ release in vertebrates $(4,5)$. In mammals, kisspeptin immunoreactive fibers are seen in close apposition with GnRH neurons (6, 7) and with GnRH axons in the median eminence (ME) in the primates (8). Furthermore, GPR54 expression has been demonstrated in GnRH neurons from a non-mammalian species, the cichlid fish, tilapia (9), suggesting that kisspeptin plays stimulatory role via its action on GnRH neurons. In 2000, Tsutsui and his colleagues discovered a novel hypothalamic neuropeptide, termed gonadotropin-inhibitory hormone $(\mathrm{GnIH})$ in the Japanese quail, Coturnix japonica that directly acts on the pituitary gland, thus impeding gonadotropin release (10). This was the first illustration of a hypothalamic neuropeptide demonstrating inhibitory effects on reproduction in any vertebrate (10).

\section{STRUCTURE OF GnIH AND GnIH RECEPTOR ORTHOLOGS IN VERTEBRATES \\ GnIH AND GnIH ORTHOLOGS}

GnIH belongs to the RFamide family of peptides as it contains RFamide motifs (Arg-Phe- $\mathrm{NH}_{2}$ ) at its C-terminus. The amino acid sequence of $\mathrm{GnIH}$ and its orthologs in various vertebrates and their phylogenetic relationship are demonstrated in Table 1 and Figure 1.

\section{Jawless and jawed fish}

In jawless fish species, GnIH orthologs have been identified and characterized in the lamprey (11) and the hagfish (12).

In jawed fish, teleosts GnIH orthologs have been identified and characterized in several species including the goldfish (13), sockeye salmon (48), grass puffer (15), tilapia (16), stickleback, tetraodon, medaka, Takifugu, and the zebrafish (14).

In this review article, all LPXRFa family of peptides $(\mathrm{GnIH}$, RFRP3, and LPXRFa) are designated as GnIH orthologs based on their "GnIH peptide-like" structure. In most fish species, GnIH gene sequence encodes three putative peptide sequences (LPXRFa$1,-2$, and -3 ), while only two putative sequences (LPXRFa- 1 and -2) are present in some teleosts such as the stickleback, tetraodon, and takifugu (14). This suggests that the structures of GnIH family of peptides are evolutionarily conserved in vertebrates.

\section{Amphibians}

In the bullfrog, frog $\mathrm{GH}$-releasing peptide (fGRP) has been identified as the amphibian $\mathrm{GnIH}$ orthologous peptide (17). In addition, using the molecular approach, another three fGRP-related peptides (fGRP-RP-1, -RP-2, and -RP-3) have been identified (19). In the European green frog, Rana RFamide (R-RFa) with LPXRFa motif has been identified (20). In the newt, four LPXRFa peptides (nLPXRFa-1,-2,-3, and -4) are predicted to be encoded in the newt LPXRFa CDNA. HPLC analysis further confirmed the existence of all four mature LPXRFa peptides in the newt brain (21). 
Table 1 | Comparison of amino acid sequences of $\mathrm{GnIH}$ and its homologous peptides from jawless fish to mammals.

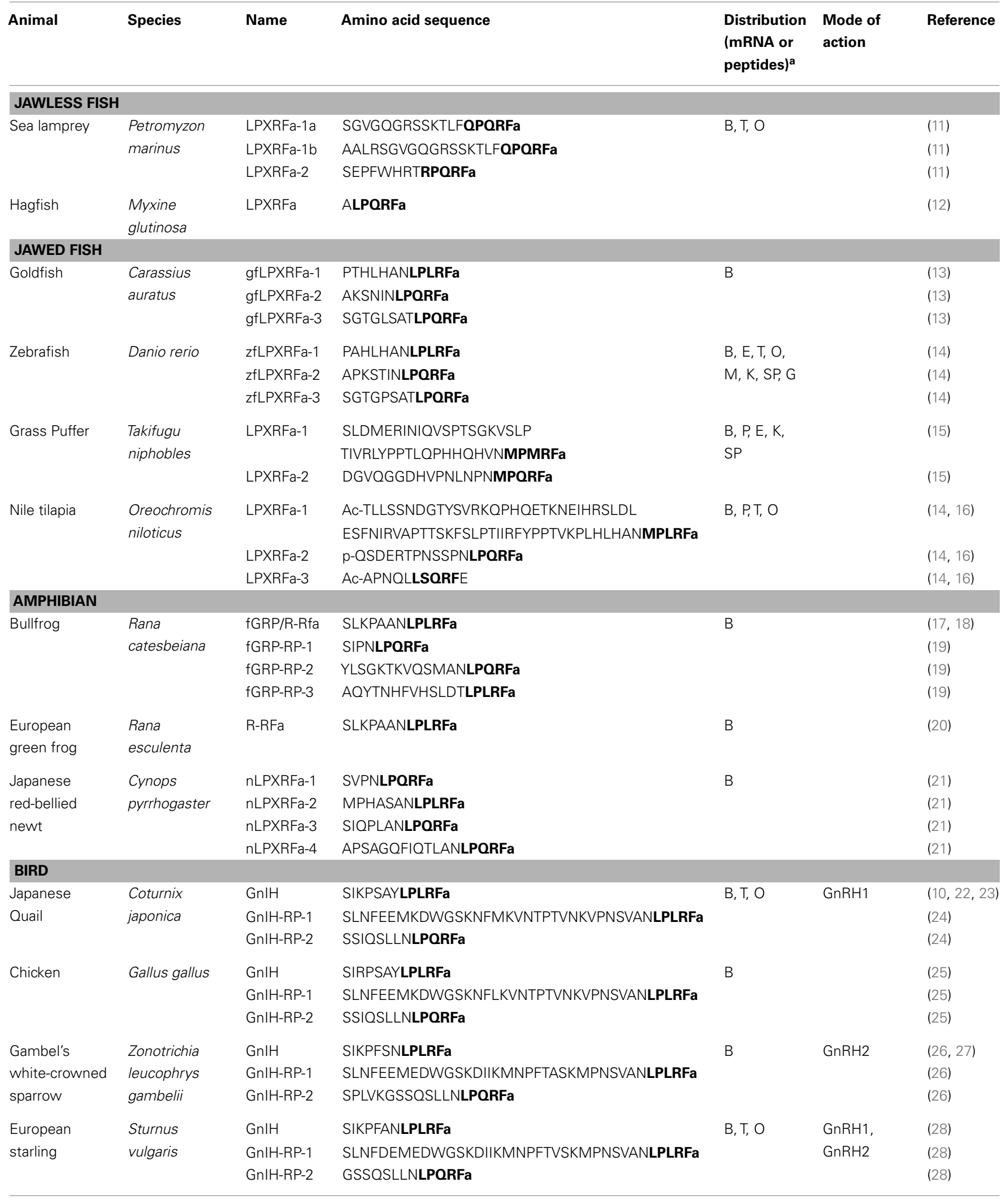


Table 1 | Continued

\begin{tabular}{|c|c|c|c|c|c|c|}
\hline Animal & Species & Name & Amino acid sequence & $\begin{array}{l}\text { Distribution } \\
\text { (mRNA or } \\
\text { peptides) }^{\mathrm{a}}\end{array}$ & $\begin{array}{l}\text { Mode of } \\
\text { action }\end{array}$ & Reference \\
\hline \multirow[t]{3}{*}{ Zebra finch } & Taeniopygia & $\mathrm{GnlH}$ & SIKPFSNLPLRFa & $\mathrm{B}$ & $\mathrm{GnRH} 1$ & $(29)$ \\
\hline & guttata & GnlH-RP-1 & SLNFEEMEDWRSKDIIKMNPFAASKMPNSVANLPLRFa & & & $(29)$ \\
\hline & & GnlH-RP-2 & SPLVKGSSQSLLNLPQRFa & & & $(29)$ \\
\hline \multicolumn{7}{|l|}{ MAMMAL } \\
\hline \multirow[t]{2}{*}{ Human being } & Homo sapiens & RFRP-1 & MPHSFANLPLRFa & $\mathrm{B}$ & & $(30)$ \\
\hline & & RFRP-3 & VPNLPQRFa & $\mathrm{B}$ & $\mathrm{GnRH} 1$ & $(30)$ \\
\hline Rhesus & Macaca & RFRP-1 & MPHSVTNLPLRFa & $\mathrm{B}$ & & (31) \\
\hline macaque & mulatta & RFRP-3 & SGRNMEVSLVROVLNLPQRFa & $\mathrm{B}$ & $\begin{array}{l}\text { GnRH1, } \\
\text { GnRH2, } \\
\text { dopamine, } \\
\beta \text {-endorphin }\end{array}$ & $(31-33)$ \\
\hline \multirow[t]{2}{*}{ Mouse } & Mus musculus & RFRP-1 & SVSFOELKDWGAKKVIKMSPAPANKVPHSAANLPLRFa & $\mathrm{B}$ & & (34) \\
\hline & & RFRP-3 & ANMEAGTRSHFPSLPQRFa & $\mathrm{B}$ & $\begin{array}{l}\text { GnRH1, } \\
\text { kisspeptin }\end{array}$ & $(34,35)$ \\
\hline \multirow[t]{2}{*}{ Rat } & Rattus & RFRP-1 & SVTFQELKDWGAKKDIKMSPAPANKVPHSAANLPLRFa & $B, E$ & & $(36)$ \\
\hline & norvegicus & RFRP-3 & ANMEAGTMSHFPSLPQRFa & B & $\begin{array}{l}\text { GnRH1, } \\
\text { kisspeptin }\end{array}$ & $(34,37-39)$ \\
\hline Syrian golden & Mesocricetus & RFRP-1 & SPAPANKVPHSAANLPLRFa & $\mathrm{B}$ & & (34) \\
\hline hamster & auratus & RFRP-3 & TLSRVPSLPQRFa & B & $\mathrm{GnRH} 1$ & $(34,40)$ \\
\hline \multirow[t]{2}{*}{ Cow } & Bos taurus & RFRP-1 & SLTFEEVKDWAPKIKMNKPVVNKMPPSAANLPLRFa & $\mathrm{B}$ & & $(41)$ \\
\hline & & RFRP-3 & AMAHLPLRLGKNREDSLSRWVPNLPQRFa & $B, P$ & & $(42)$ \\
\hline \multirow[t]{2}{*}{ Sheep } & Ovis aries & RFRP-1 & SLTFEEVKDWGPKIKMNTPAVNKMPPSAANLPLRFa & $\mathrm{B}$ & & $(43,44)$ \\
\hline & & RFRP-3 & VMAHLPLRLGKNREDSLSRRVPNLPORFa & $B, P$ & $\begin{array}{l}\text { GnRH1, } \\
\text { NPY, POMC, } \\
\text { orexin, MCH }\end{array}$ & $(43-46)$ \\
\hline \multirow[t]{2}{*}{ Pig } & Sus scrofa & LPXRF-1 & SLNFEELKDWGPKNVIKMSTPVVNKMPPLAANLPLRFa & $\mathrm{B}, \mathrm{M}, \mathrm{O}, \mathrm{E}$ & & $(47)$ \\
\hline & & LPXRF-3 & AIASLPLRFGRNTEDSMSRPVPMLPQRFa & $K, A, U, P g$ & & \\
\hline
\end{tabular}

${ }^{a} B$, brain; P, pituitary; $E$, eye; T, testis; $O$, ovary; $M$, muscle; $K$, kidney; SP, spleen; Gl, gill; $A$, adrenal gland; U, uterus; Pg, parotid gland. The identical $C$-terminal LPXRFamide ( $X=$ Leu or Gln) motif sequences are in bold font.

\section{Birds}

$\mathrm{GnIH}$ peptides have been identified in various avian species such as chicken, zebra finches, starlings, and sparrows (10, 24, 28, 29).

\section{Mammals}

Orthologs of GnIH have also been determined in the mammalian species $(43,49,50)$. In mammals, three different RFamide-related peptides (RFRP), including RFRP-1, -2, and -3, were initially identified from the bovine and human brain CDNA, whereas only two RFRPs (RFRP-1 and/or RFRP-3) were discovered in rodents (51, 52). The mammalian GnIH orthologs, RFRP-1 and -3, possess the LPXRFamide ( $\mathrm{X}=\mathrm{Leu}$ or Gln) peptide, which is absent in the RFRP-2 ortholog (53). Therefore, it has been concluded that RFRP-1 and RFRP-3 serve as the functional mammalian GnIH orthologs.

\section{GnIH RECEPTOR}

The receptor for GnIH family of peptides belongs to the seven transmembrane G protein-coupled receptor (GPCR or GPR) family. Two potential GnIH receptors (GPR147 and GPR74) have been identified in vertebrates and GPR147 has been accepted as a potent receptor for GnIH. The summary of GnIH-homologous peptides and its receptor $(\mathrm{GnIHR}=\mathrm{GPR} 147)$ and its orthologs in various vertebrates and their phylogenetic relationship are demonstrated in Table 2 and Figure 2.

\section{Jawless and jawed fish}

In jawless fish, there is no report on identification of $\mathrm{GnIH}$ receptor to date. In jawed fishes, GnIH receptors have been identified in several species; where GPR147 has been identified in the grass puffer (15), goldfish (66), zebrafish (14), and tilapia (16), and GPR74 has been identified in several teleosts species $(14,16)$. In most 


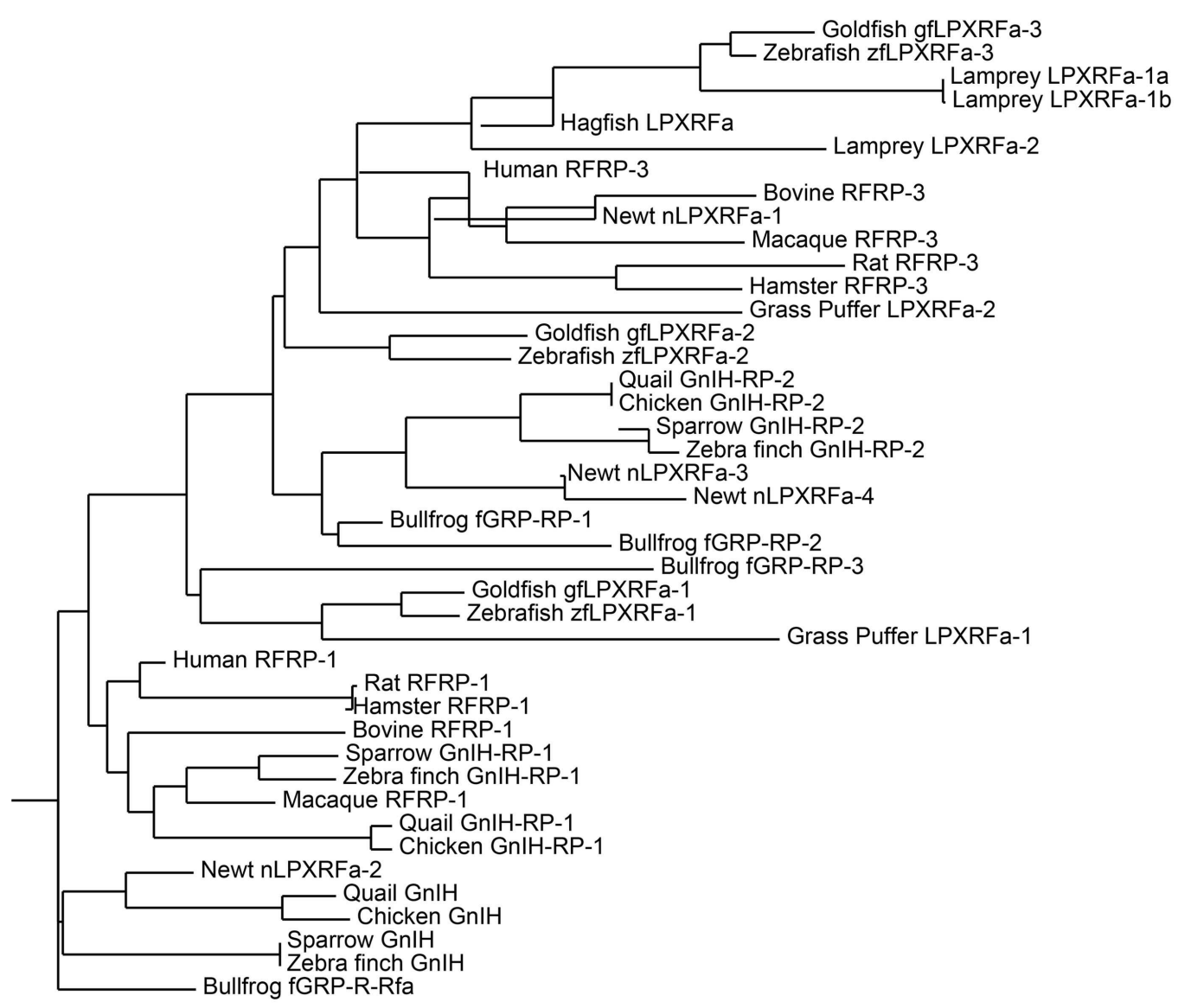

FIGURE 1 | Phylogenetic tree of GnIH and its homologous peptides sequences in vertebrates. The phylogenetic tree was constructed by MEGA 3.1 using the neighbor-joining method. The amino acid sequences analyzed for the phylogenetic tree construction are listed in Table 1.

teleosts, only one GnIH receptor gene has been identified, while in the zebrafish, three different GnIH receptor gene types (gnihrl, gnihr2, and gnihr3) have been isolated (14). However, the binding affinities of teleost GPR147 and GPR74 to GnIH peptides have not been characterized. Our recent study has shown that tilapia GPR147 (tiLPXRFa-R) has strong affinity to tilapia LPXRFa-2 peptides through both cAMP/PKA and $\mathrm{Ca}^{+2} / \mathrm{PKC}$ pathways (16).

\section{Birds}

In the avian species, two receptors (GPR74 and GPR147) have been identified and further characterization has revealed GPR147 as the potent receptor for the avian $\mathrm{GnIH}$ based on their binding affinity to GnIH and RFRP-3 peptides $(25,59)$.

\section{Mammals}

In mammals, two receptors (GPR74 and GPR147) have been identified $(36,44,67,68)$. GPR147 couples to $G_{\alpha i}$ protein, which is involved in inhibiting the production of cAMP (36). Therefore, GPR147 is generally accepted as the candidate receptor for GnIH and RFRP-3 in birds and mammals because of its stronger inhibitory effect on $\mathrm{G}_{\alpha \mathrm{i}}$ mRNA expression in COS-7 cells, as compared to that of GPR74 $(25,52,69)$. However, other studies have shown that GPR147 receptor also tends to bind to $\mathrm{G} \alpha_{\mathrm{i} 3}$ and $\mathrm{G} \alpha_{\mathrm{s}}$ proteins, while GPR74 binds to $\mathrm{G} \alpha_{\mathrm{i} 2}, \mathrm{G} \alpha_{\mathrm{i} 3}, \mathrm{G} \alpha_{\mathrm{o}}$, and $\mathrm{G} \alpha_{\mathrm{s}}$ proteins (70).

\section{DISTRIBUTION OF GnIH AND GnIHR \\ DISTRIBUTION OF GnIH NEURONS IN THE BRAIN}

Compared to mammals and birds, in other non-mammalian vertebrate species, studies describing the distribution of GnIH expression are very few due to limited GnIH gene sequences and the lack of specific antibodies to non-mammalian GnIH orthologous peptides. The distribution pattern of $\mathrm{GnIH}$ neurons in the brain of various vertebrate species are illustrated in Figure 3 (71).

\section{Jawless and jawed fish}

In the brain of sea lamprey, the expression of lamprey LPXRFa mRNA as well as lamprey LPXRFa-immunoreactive cells has been detected in the bed nucleus of the tract of the postoptic commissure (nTPOC) in the hypothalamus (11). Lamprey LPXRFaimmunoreactive fibers are widely seen in the brain and a few fibers are seen in the neurohypophysis (11).

In jawed fish species, such as the goldfish, in situ hybridization study has shown the expression of GnIH mRNA in the nucleus posterioris periventricularis $(\mathrm{NPPv})$ in the hypothalamus (13). Using antibodies to avian GnIH and fGRP, the distribution of 
Table 2 | List of GnIH receptor (GPR147) and its homologous sequences found or predicted from jawless fish to mammals.

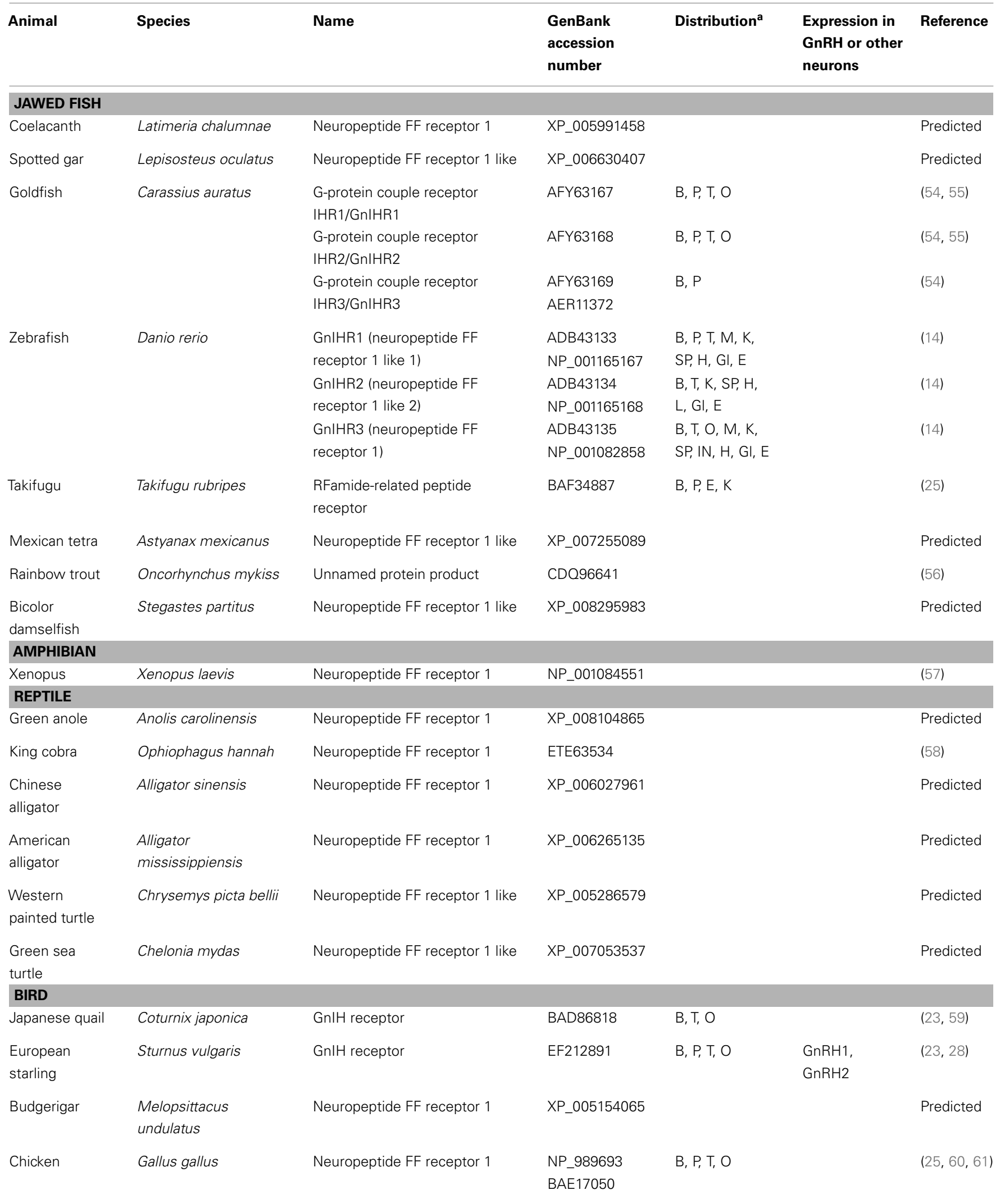


Table 2 | Continued

\begin{tabular}{|c|c|c|c|c|c|c|}
\hline Animal & Species & Name & $\begin{array}{l}\text { GenBank } \\
\text { accession } \\
\text { number }\end{array}$ & Distribution $^{a}$ & $\begin{array}{l}\text { Expression in } \\
\text { GnRH or other } \\
\text { neurons }\end{array}$ & Reference \\
\hline \multicolumn{7}{|l|}{ MAMMAL } \\
\hline Human being & Homo sapiens & Neuropeptide FF receptor 1 & NP_071429 & $B, P$ & & $(30,36)$ \\
\hline Mouse & Mus musculus & Neuropeptide FF receptor 1 & NP_001170982 & & $\begin{array}{l}\text { GnRH, } \\
\text { kisspeptin }\end{array}$ & $(35,62,63)$ \\
\hline Rat & Rattus norvegicus & Neuropeptide FF receptor 1 & NP_071627 & $B, E$ & $\begin{array}{l}\text { GnRH, } \\
\text { kisspeptin, } \\
\text { dopamine }\end{array}$ & $(36,39)$ \\
\hline $\begin{array}{l}\text { Syrian golden } \\
\text { hamster }\end{array}$ & Mesocricetus auratus & GPR147 & ACY39880 & $\mathrm{B}, \mathrm{P}, \mathrm{T}$ & & $(64,65)$ \\
\hline Sheep & Ovis aries & Neuropeptide FF receptor 1 & ABW08098 & $\mathrm{B}$ & & $(44)$ \\
\hline Pig & Sus scrofa & Neuropeptide FF receptor 1 & HQ681286 & $\begin{array}{l}B, P, O, K, E, U \\
A, I N, S\end{array}$ & & $(47)$ \\
\hline
\end{tabular}

${ }^{a} B$, brain; P, pituitary; $E$, eye; $T$, testis; $O$, ovary; $M$, muscle; K, kidney; $S P$, spleen; Gl, gills; $H$, heart; $L$, liver; IN, intestine; $A$, adrenal gland; $U$, uterus.

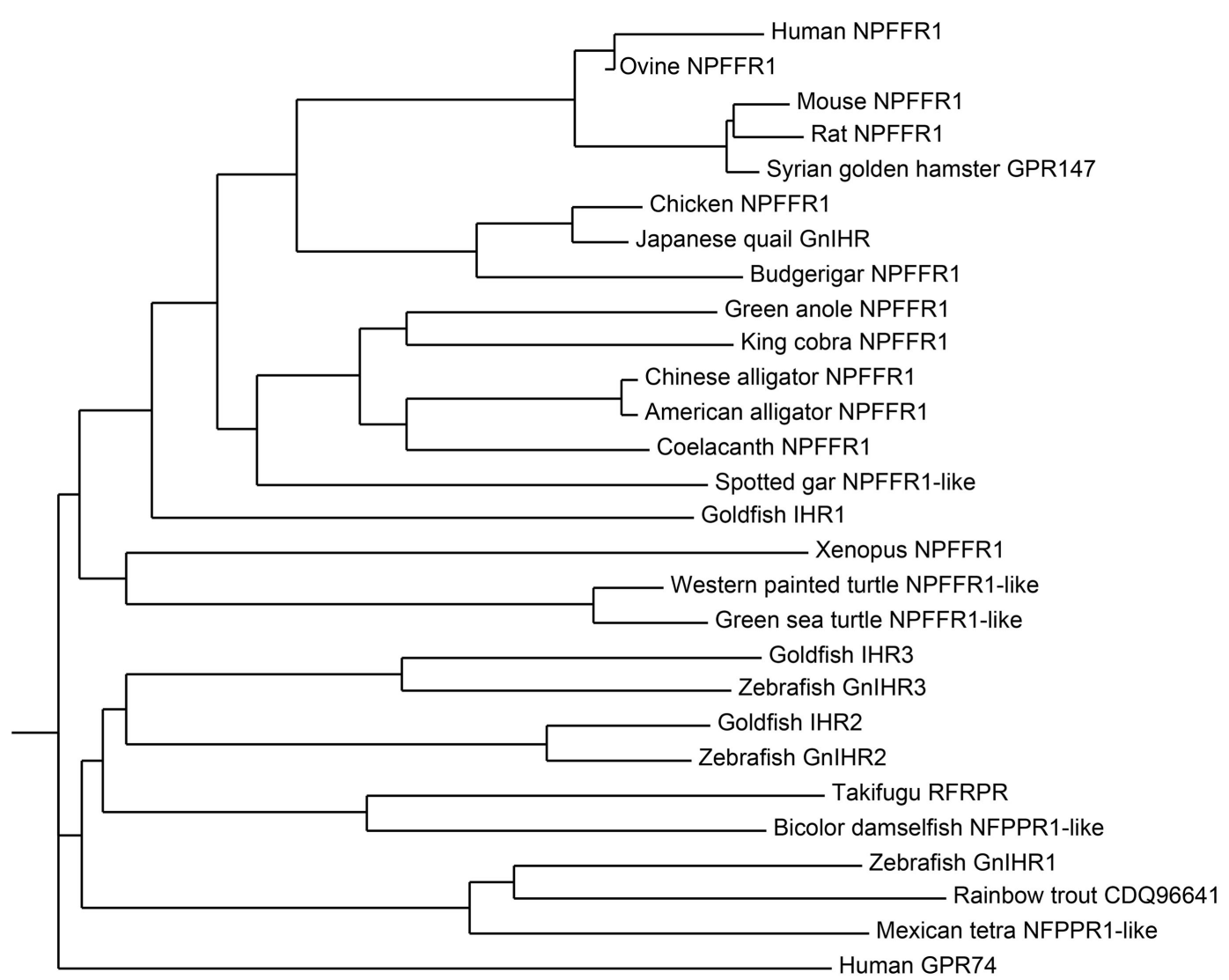

FIGURE 2 | Phylogenetic tree of GnIH receptor (GPR147) and its homologous sequences in vertebrates. The phylogenetic tree was constructed by MEGA 3.1 using the neighbor-joining method. GenBank accession numbers for the sequences are listed in Table 2. 

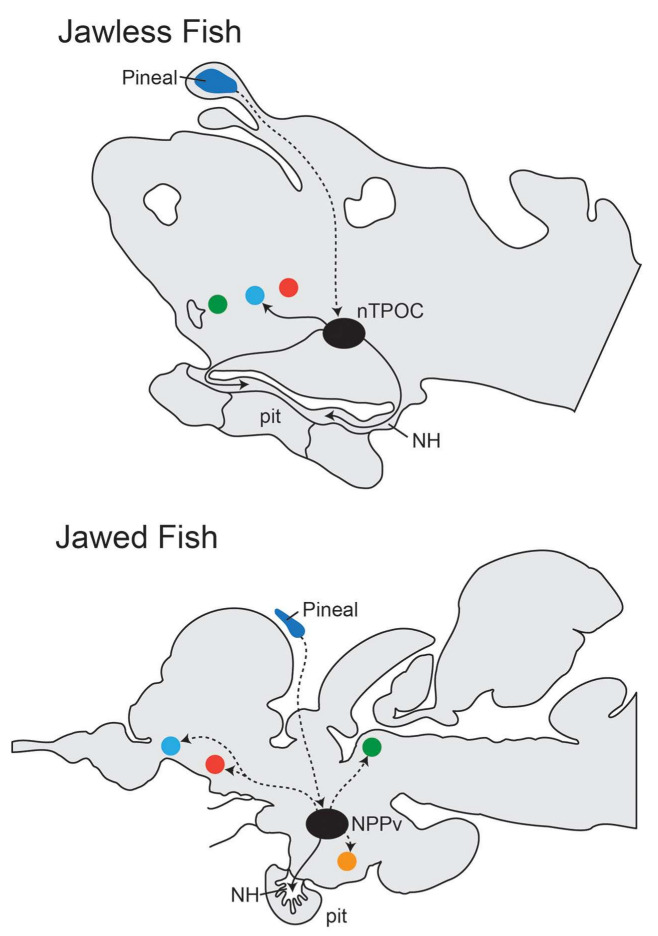

Amphibians

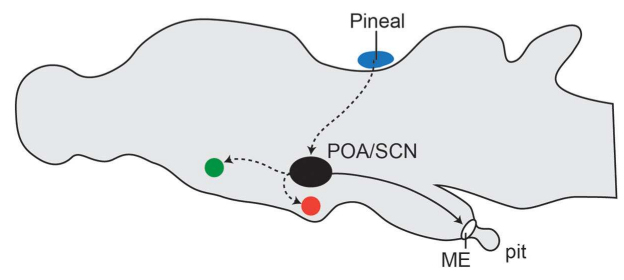

FIGURE 3 | Comparison of localization of GnIH cells and their associations with other neural systems in the brain from jawless fish, jawed fish, amphibians, birds, and mammals. In jawless fish (sea lamprey), LPXRFa-cells are localized in the bed nucleus of the tract of the postoptic commissure (nTPOC) in the hypothalamus (11). In jawed fish (goldfish, salmon, and carp), LPXRFa-immunoreactive cells are seen in the nucleus posterioris periventricularis (NPPv) $(13,48,72)$. In amphibians (bullfrog and newt), LPXRFa-neurons are seen in the anterior preoptic area (POA) and/or the suprachiasmatic nucleus (SCN) $(17,18,20,21)$. In birds, the $\mathrm{GnIH}$ neurons are present in the PVN. In mammals and birds, $\mathrm{GnIH}$ neurons project to the median eminence (ME). In mammals, GnIH neurons are localized in the dorsomedial nucleus of the hypothalamus $(\mathrm{DMH})$ and in the paraventricular nucleus (PVN). In jawless fish (sea lamprey), LPXRFa-immunoreactive fibers are seen in the neurohypophysis (NE), suggesting action of $\mathrm{GnIH}$ on the

\section{Birds}
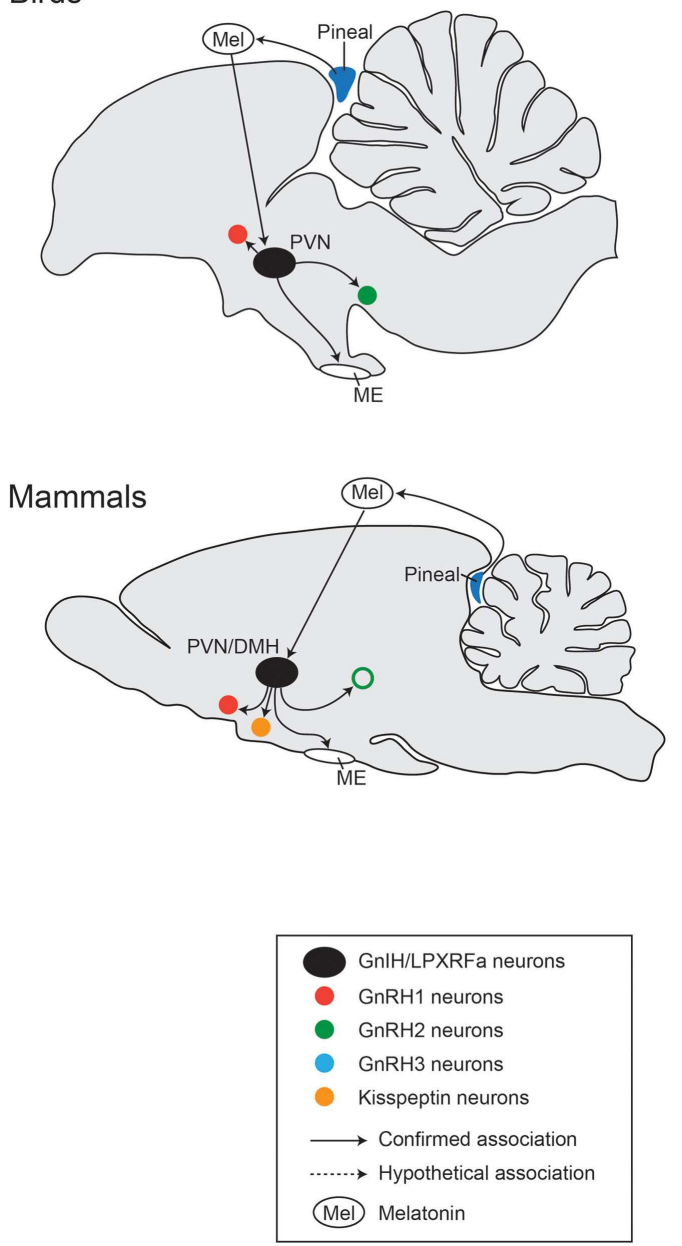

pituitary (pit) cells. In jawed fish, LPXRFa-immunoreactive fibers are present in the pituitary. In amphibians, birds, and mammals, LPXRFa/GnlH fibers are terminated in the ME. In birds and mammals, GnIH cells (black circle) associated with several other neurons such as $\mathrm{GnRH}$ neuron types: $\mathrm{GnRH} 1$ (red circle), GnRH2 (green circle), and $\mathrm{GnRH} 3$ (blue circle) neurons. The open circle with green indicates the presence of $\mathrm{GnRH} 2$ neurons only in certain mammalian species such as primates but not in rodents (73). In some mammals, GnlH fibers are also closely associated with kisspeptin neurons (yellow circle). GnIH neural functions are regulated by melatonin (Mel) derived from the pineal gland (dark blue) or eyes. In jawed and jawless fish, the effect of melatonin on $\mathrm{GnIH}$ neurons is still unknown, but there might be direct projection from the pineal gland to $\mathrm{GnIH}$ neurons in the hypothalamus (74-76). Confirmed association is indicated by the line, and unconfirmed hypothetical association is indicated by the dotted line.
$\mathrm{GnIH}$ orthologs-like immunoreactivity has been examined in the brain of several teleosts including the goldfish (13), sockeye salmon (48), and the Indian major carp (72). In the sockeye salmon and the Indian major carp, the distribution pattern of fGRP/GnIHimmunoreactive cells is similar to GnIH mRNA expression in the NPPv of the goldfish $(13,48,72)$, suggesting that the presence of $\mathrm{GnIH}$ neurons in the NPPv is a common pattern in teleosts.

The presence of fGPR/GnIH-immunoreactive fibers have been reported in several brain regions including in the olfactory bulb, telencephalon, optic tectum, mesencephalon, diencephalon, and the spinal cord $(13,48,72)$. In the goldfish and sockeye salmon, the presence of fGPR-immunoreactive fibers has also been noted in the pituitary $(13,48)$. In the pituitary of the Indian major carp, GnIH-immunoreactive cells and fibers have been detected in the proximal pars distalis region only during the early developmental stage, but not in adults (72). However, in the Indian major carp, GnIH-immunoreactive cells are also seen in several mesencephalic regions, such as the nucleus of medial longitudinal 
fascicle and the occulomotor nucleus (72), which needs further verification by in situ hybridization with specific $\mathrm{GnIH}$ gene sequence in the Indian major carp. Similarly, in the goldfish, fGRPimmunoreactive cells have been reported in the terminal nerve of the olfactory bulb, where no GnIH mRNA is expressed (13), which indicates the fGRP antibody has cross reactivity to other unknown RFamide peptides. Therefore, to identify the targets of GnIH neurons in the brain and in the pituitary more precisely, a specific antibody to fish $\mathrm{GnIH}$ orthologs peptide needs to be generated.

\section{Amphibians}

In the brain of the European green frog, R-RFa-containing neurons are localized in the hypothalamus, which includes the anterior preoptic area (POA), the suprachiasmatic nucleus (SCN), and the dorsal and ventral hypothalamic nuclei (20). R-RFa-containing fibers are widely distributed throughout the brain from the olfactory bulb to the brainstem, and are particularly abundant in the external layer of the ME (20). In the bullfrog, fGRP neurons are mainly seen in the telencephalon and the diencephalon including the medial septum, nucleus of the diagonal band of Broca, anterior POA and the SCN $(17,18)$. fGRP-immunoreactive fibers are widely distributed throughout the brain including mesencephalic and rhombencephalic regions, and are terminate in the ME (17). In the newt brain, nLPXRFa mRNA and the peptide (with antifGRP serum) are expressed only in the SCN in the hypothalamus (21). Similar to frogs, fGRP-immunoreactive fibers are seen in the mesencephalic and rhombencephalic regions and terminate in the ME (21).

\section{Reptiles}

In the Japanese grass lizard, GnIH-immunoreactive neurons are seen in the nucleus accumbens, paraventricular nucleus (PVN), and upper medulla, and GnIH fibers are distributed in the third ventricle, the paraventricular organ, and the ME (77).

\section{Birds}

In the avian species, majority of the hypothalamic GnIH neuronal cell bodies are present in the PVN, with the main projections extending to the ME $(10,26,78,79)$. However, in the ME of Rufous-winged sparrows, there are no GnIH fibers (80), although expression of $\mathrm{GnIH}$ receptors has been shown in the pituitary (69). Additionally, the diencephalic and mesencephalic regions of the avian brain have extensive distribution of GnIH fibers.

\section{Mammals}

In rodents, $\mathrm{GnIH}$ neurons are concentrated within the dorsomedial nucleus of the hypothalamus (DMH), where abundant fibers project to the hypothalamic and limbic structures (34). In the ovine species, GnIH neurons are widespread in the brain, where they are present throughout the DMH, PVN, and the mediobasal hypothalamus (43). Recently, using transgenic rats carrying an enhanced green fluorescent protein (EGFP) tagged to the $\mathrm{GnIH}$ promoter, another population of smaller EGFP-positive neurons were seen in the ventromedial hypothalamus (VMH), which was not detected previously by GnIH immunohistochemistry (81). The mammalian GnIH fiber terminals project to the external layer of the ME $(30,31,43,64)$, suggesting the action of GnIH on the pituitary via the blood vasculature, which is supported by the measurement of $\mathrm{GnRH}$ peptide concentration in hypophyseal portal blood in ewes (82). However, GnIH-immunoreactive fibers are absent in the ME of hamsters $(34,40)$ and Wistar rats $(83)$.

\section{DISTRIBUTION OF GnIH RECEPTORS IN THE BRAIN AND PITUITARY}

In most vertebrates, GnIH receptors (GPR147) are mainly expressed in the pituitary and in several brain regions including the hypothalamus and the spinal cord $(14,25,30,59,84)$, most of which have been examined mainly by RT-PCR or Southernblot analysis. However, to date, detail neuroanatomical information of $\mathrm{GnIH}$ receptor localization in the vertebrate brain is very limited (28).

\section{Jawless and jawed fish}

There is no report demonstrating the distribution of GnIH receptor in jawless species. However, in jawed fish species, the zebrafish, the expression of three $\mathrm{GnIH}$ receptors have been detected in the brain by RT-PCR (14). In the zebrafish, two GnIH receptors genes (gnihr1 and gnihr3) are expressed in the pituitary (14). In the grass puffer and the tilapia, both $\mathrm{GnIH}$ and $\mathrm{GnIH}$ receptor genes are expressed in the brain and pituitary $(15,16)$. Furthermore, our recent study in the tilapia has shown the co-expression of GnIH receptor gene (lpxrf-r) in LH and FSH cells by double in situ hybridization (16).

\section{Birds and mammals}

In the quail, RT-PCR has shown GnIH receptor mRNA expression in the cerebrum, diencephalon, mesencephalon, and the spinal cord (59). In human beings, the expression of $\mathrm{GnIH}$ receptor gene has been shown in the hypothalamus and in the pituitary by RT-PCR (30). In the human pituitary, gene expression of $\mathrm{GnIH}$ receptors in LH cells has been shown by in situ hybridization (30).

\section{DISTRIBUTION OF GnIH AND GnIH RECEPTORS IN THE GONADS}

In several vertebrate species, the expression of $\mathrm{GnIH}$ and $\mathrm{GnIH}$ receptors has been reported in some peripheral tissues including the gonadal tissues (69) (Tables 1 and 2), indicating the role of $\mathrm{GnIH}$ in ovarian or testicular maturations $(65,85)$. Expression of GnIH and/or GnRH receptor has been shown in the gonadal tissues by RT-PCR, in situ hybridization, and immunohistochemistry $(32,86)$.

\section{Jawless and jawed fish}

In the sea lamprey, LPXRFa mRNA is expressed in the testis and ovary (11).

In the zebrafish, GnIH and three GnIH receptor genes (gnihrl, gnihr2, and gnihr3) are expressed in the testis, and $\mathrm{GnIH}$ and $\mathrm{GnIH}$ receptor gene (gnihr3) are expressed in the ovary (14). Similarly, in the goldfish, two out of three GnIH receptor types ( $g n r h 1$ and gnrh2) are expressed in the testis and ovary (55). In the tilapia, LPXRFa and LPXRFa-R (GPR147) mRNAs are expressed in the gonads (16). However, in the grass puffer, there is no expression of LPXRFa and LPXRFa-R mRNAs in the gonads (15). In situ hybridization study in the goldfish has shown expression of gnrh1 and gnrh2 genes in the oocytes only before the cortical alveolus stage, but not at the vitellogenic stage (55). In the testis of 
goldfish, expression of two GnIH receptor gene types have been reported in the interstitial tissue (55). In vitro treatment of goldfish gonadal cell culture with GnIH peptides (gfLPXRFa-2 and gfLPXRFa-3) has no effect on the mRNA expression of genes involved in steroidogenesis in ovarian cells, while in testicular cell culture, GnIH peptides significantly upregulate the expression of genes involved in testosterone biosynthesis, but suppress the CYP9 gene, which is responsible for aromatization of testosterone (55).

\section{Amphibians and reptiles}

There is no report demonstrating the presence of either GnIH or $\mathrm{GnIH}$ receptors in gonadal tissues of amphibian species.

In reptiles, the garden lizard, Calotes versicolor, has $\mathrm{GnIH}$ immunoreactivity in the granulosa cells of previtellogenic follicles and stroma cells, which is relatively higher during inactive phase, but lower during the active preovulatory phase suggesting inverse correlation with circulating estradiol level (87).

\section{Birds}

In birds, $\mathrm{GnIH}$ and $\mathrm{GnIH}$ receptor gene expression has been shown in the testis and ovary by RT-PCR $(23,60,88)$. Furthermore, in situ hybridization and immunohistochemical approaches have revealed the presence of GnIH mRNA and peptides in the ovarian thecal and granulosa cells, testicular interstitial and germ cells, and pseudostratified columnar epithelial cells in the epididymis $(23,88)$. GnIH receptor is also localized in the ovarian thecal and granulosa cell layers, and testicular interstitial, germ cells, and spermatocytes $(23,60,88)$. In the European starlings, melatonin upregulates the expression of GnIH mRNA in the gonads. Furthermore, GnIH and melatonin significantly decrease testosterone secretion from LH/FSH-stimulated testes (89), suggesting that $\mathrm{GnIH}$ is involved in the seasonal regulation of testicular maturation.

\section{Mammals}

In the mammalian species, the expression of $\mathrm{GnIH}$ and $\mathrm{GnIH}$ receptors and the role of $\mathrm{GnIH}$ in gonadal maturation have been well demonstrated $(32,85)$. In the Syrian hamster, the presence of $\mathrm{GnIH}$ and $\mathrm{GnIH}$ receptor has been shown in spermatocytes and in spermatids, but not in the Leydig cells of the testis (65). In the rhesus macaque, $\mathrm{GnIH}$ and $\mathrm{GnIH}$ receptors are expressed in the Leydig cells, spermatogonia, and spermatocytes, and in the ovarian preantral follicles and granulosa cells (88). In the ovary of mice, GnIH is expressed in the granulosa cells, antral follicles, and the luteal cells (90). Similarly, in the pig, GnIH and $\mathrm{GnIH}$ receptor immunoreactivity has been shown in the luteal cells and in the granulosa and theca cells of the antral follicles during proestrus and estrus (47). In human beings, the expression of GnIH and GnIH receptor has been shown in the granulosa cell layer of large preovulatory follicles and the corpus luteum as well as in the primary cultures of human granulosa-lutein cells (91). A very recent study in mice has reported that GnIH (RFRP-3) treatment reduces germ cell proliferation and survival but increases apoptosis with a reduction of testosterone synthesis in the testis in a dose-dependent manner (92). Similarly, mice treated in vivo with $\mathrm{GnIH}$ for 8 days show dose-dependent changes in ovarian follicular morphology, reduction in the number of healthy antral follicles, an increase in the number of atretic follicles with low dose of $\mathrm{GnIH}$ (100 ng/day), and appearance of abnormal follicles at high doses ( $2 \mu \mathrm{g} /$ day) (93). In vitro treatment of mice ovary with GnIH suppresses the production of ovarian progesterone synthesis and reduces steroidogenic enzymes such as $3 \beta$-hydroxysteroid dehydrogenase (93).

\section{ASSOCIATION OF GnIH SYSTEM WITH OTHER NEURAL SYSTEMS}

Based on the morphological distribution of $\mathrm{GnIH}$ and $\mathrm{GnIH}$ receptors in the brain and pituitary, their potential role as well as their mechanism of action have been well demonstrated in the avian and the mammalian species. In birds and mammals, $\mathrm{GnIH}$ fibers are seen in close proximity to the GnRH neurons in the POA (22, 28, 30, 45, 78-81) (Figure 3). Furthermore, the expression of GnIH receptor has been shown in GnRH1 neurons (28, 40, 94-96). In monkeys and birds, GnIH neurons send projections to midbrain GnRH2 neurons that express GPR147 $(28,30,78)$. However, in ray-fin fishes, neural associations between $\mathrm{GnIH}$ with other hypothalamic neurons are very limited due to the lack of specific antibody.

\section{Jawless and jawed fish}

In the sea lamprey, lamprey GnIH (LPXRFa-2) immunoreactive fibers have been observed in close apposition to GnRH-III neurons (11).

A recent study in the dwarf gourami demonstrated that medaka GnIH (RFRP2 = LPXRFa-2) inhibits the pacemaker activity of GnRH3 neurons in the terminal nerve (97), suggesting the functional association of $\mathrm{GnIH}$ fibers with non-hypothalamic $\mathrm{GnRH} 3$ neurons. This suggests the action of GnIH on GnRH neurons could be evolutionarily conserved in vertebrates, which remains to be further confirmed in other fish species with fish-specific GnIH antibodies.

\section{Birds}

Interactions of GnIH with GnRH1 (c-GnRH-I) neurons are seen in several avian species including the Japanese quail, European starling, song sparrow, house sparrow, and the zebra finch $(22,28$, 29, 34, 78). In Gambel's white-crowned sparrow and European starling, GnIH fibers are also closely associated with GnRH2 (cGnRH-II) neurons $(27,28)$. Furthermore, expression of GnIH receptor mRNA has been identified in GnRH1 and GnRH2 neurons in the brain of the European starling (28).

\section{Mammals}

In the rhesus macaque, GnIH fibers are observed in close proximity to GnRH1 and GnRH2 neurons (31). A morphological study in the sheep using a retrograde tracer has shown fiber projection of GnIH neurons to several other hypothalamic neuropeptides-containing neurons, such as to neuropeptide Y, pro-opiomelanocortin (POMC), orexin, melanin-concentrating hormone, corticotrophin-releasing hormone, and oxytocin neurons (46). Similarly, GnIH fibers are seen in close association with POMC neurons in mice (98). In rats, GnIH fibers are closely associated with kisspeptin neurons in the rostral periventricular region of the third ventricle region (39), and in the arcuate nucleus of mice (35), which is supported by the expression of GPR147 mRNA in 
kisspeptin neurons $(35,95)$. On the other hand, very few $\mathrm{GnIH}$ cells $(3-7 \%)$ receive kisspeptin fibers in mice (35). Interestingly, in mice, GnIH neurons also co-express neurokinin B (Tac2) and its receptor (Tacr3) mRNAs (35).

In addition to neuropeptides, $\mathrm{GnIH}$ neurons are also associated with neurotransmitters. In the rhesus macaque, GnIH fibers are closely associated with dopamine and $\beta$-endorphin neurons (31). In mice, morphological and electrophysiological studies have revealed functional interactions between $\mathrm{GnIH}$ with glutamatergic neurons but not with cholinergic or GABAergic neurons (99). In rats, GPR147 is expressed in dopamine neurons (36). In addition, a recent report in rats has shown no co-expression of $\mathrm{GnIH}$ neurons with GABA (39). In rats, GnIH neural population in the DMH express 11 types of serotonin receptors (63). Similar observation has been reported in the Japanese grass lizard (77). These results indicate multiple functions of the $\mathrm{GnIH}$ system, in addition to its inhibitory action on reproduction.

\section{FUNCTION OF GnIH-GnIHR SIGNALING IN VERTEBRATE REPRODUCTION \\ ROLE OF GnIH IN GONADOTROPIN SYNTHESIS AND RELEASE}

As the name of the peptide indicates, GnIH peptides act as inhibitory factor in the control of reproduction mainly in birds and mammals $(10,34)$. Similar findings have been reported in various vertebrate species (52) (Table 3). On the contrary, in rayfin fishes, the role of $\mathrm{GnIH}$ peptides in the control of gonadotropin release has been debatable.

\section{Jawless and jawed fish}

In female lampreys, treatment of lamprey GnIH (LPXRFa2) stimulates the expression of lamprey GnRH-III protein in the hypothalamus and GTH $\beta$ mRNA expression in the pituitary (11).

The first physiological study demonstrating the role of teleost GnIH peptides (goldfish LPXRFa-1, -2, and -3 peptides) was reported in the sockeye salmon, in which goldfish LPXRFa peptides increase the release of $\mathrm{LH}, \mathrm{FSH}$, and growth hormone $(\mathrm{GH})$ from cultured pituitary cells (48). Similarly, an in vivo study in the goldfish has shown that GnIH significantly increases pituitary levels of mRNAs for $\mathrm{LH} \beta$ and $\mathrm{FSH} \beta$ in a reproductive stage-dependent manner (100). Goldfish GnIH (gfLPXRFa-1) peptide treatment to the grass puffer significantly stimulates FSH $\beta$ and LH $\beta$ gene expression (15). Our recent study in the female tilapia has shown that tilapia LPXRFa-2 peptides positively increase LH and FSH release in vitro and in vivo (16).

In contrast, intraperitoneal administration of zebrafish $\mathrm{GnIH}$ (LPXRFa-3) to goldfish decreases the plasma LH levels (14). Similarly, inhibitory effects of GnIH on circulating serum LH levels have been demonstrated during the early to later stages of recrudescence in the goldfish $(66,100)$. These differences in gonadotropin responses to $\mathrm{GnIH}$ seen in different and in the same fish species (summarized in Table 3 ) can be explained by a recent physiological study conducted in the goldfish (54). Intraperitoneal injections of goldfish GnIH-II peptide and GnIH-III peptide significantly decreases FSH $\beta$ mRNA levels, whereas in vitro application of $\mathrm{GnIH}$ has no effect on gonadotropin synthesis. However, an inhibition of GnRH-stimulated $\mathrm{LH} \beta$ and FSH $\beta$ synthesis has been observed when GnIH-III was applied to primary pituitary cell cultures (54). Collectively, these reports in ray-fin fish species suggest that the inhibitory action of $\mathrm{GnIH}$ on gonadotropin synthesis/release is closely associated with the reproductive stages in fish, which can be modulated by GnRH-dependent mechanism of action as in birds and mammals $(26,95)$.

\section{Birds and mammals}

In birds and mammals, GnIH reduces gonadotropin release from the anterior pituitary $(10,34)$, which has been extensively reviewed previously. RFRP-3 inhibits the synthesis and/or release of gonadotropins across various mammalian species, and recently, it has also been found that RFRP-1 is capable of inhibiting the release of gonadotropins in hamsters (40). Indeed, in sheep, GnIH (GnIH-3) peptide levels in the portal blood are around $2-3 \mathrm{pg} / \mathrm{ml}$ during the breeding season but increase to $4-8 \mathrm{pg} / \mathrm{ml}$ during the non-breeding season (82). In rats, the central administration of GnIH (RFRP3-8) peptides has shown to suppress the circulating $\mathrm{LH}$ levels at the dose of $1 \mathrm{nmol} /$ injection in vivo, and $\mathrm{GnIH}$ suppresses gonadotropin secretion from pituitary culture at the concentration of $10^{-8} \mathrm{M}$ in vitro (108). However, in rufous-winged sparrows (Aimophila carpalis), there is no effect of peripheral injections of GnIH on basal plasma LH levels and on GnRH-elicited LH secretion (104). This could be due to the shorter half-life of $\mathrm{GnIH}$ peptides in vivo compared with in vitro. In ewes, the half-life of peripherally injected $\mathrm{GnIH}$ in portal blood is $6.03 \pm 0.30 \mathrm{~min}$ in vivo (82). While under in vitro condition, the half-life of $\mathrm{GnIH}$ (RFRP3-8) peptides is $14.3 \mathrm{~min}$ in rat serum (108).

\section{ROLE OF GnIH IN SOCIO-SEXUAL BEHAVIORS}

Gonadotropin-inhibitory hormone is also involved in the regulation of reproductive and social behaviors (Table 3) (109).

\section{Jawless and jawed fish}

The role of $\mathrm{GnIH}$ orthologs in socio-sexual behaviors has not been demonstrated in jawless and jawed fish species. Nevertheless, a recent study has suggested $\mathrm{GnIH}$ as a regulator of neuroestrogen synthesis (110) and the potential involvement of neuroestrogen in socio-sexual behaviors has been demonstrated in several jawed fish species. In a sex-changing fish (Lythrypnus dalli), socially induced decrease in brain aromatase levels correspond with increased aggression (111). Male Endler guppy (Poecilia reticulata) treated with the aromatase inhibitor show reduce of courtship activities (112). In the African cichlid fish (Astatotilapia burtoni), males treated with aromatase inhibitor show decrease aggressive, but not reproductive behaviors (113).

\section{Birds}

Female white-crowned sparrows injected with GnIH show inhibition of copulation-solicitation with the reduction of circulating LH levels (27). In the European starlings, there is close association between social and breeding status and $\mathrm{GnIH}$ levels in the brain (114). Indeed, bird pairs (male and female) with nest (winner) have significantly different numbers of GnIH peptide-producing cells than those without nest (losers), suggesting that GnIH may 
Table 3 | Functions of GnlH and its homologous peptides from jawless fish to mammals

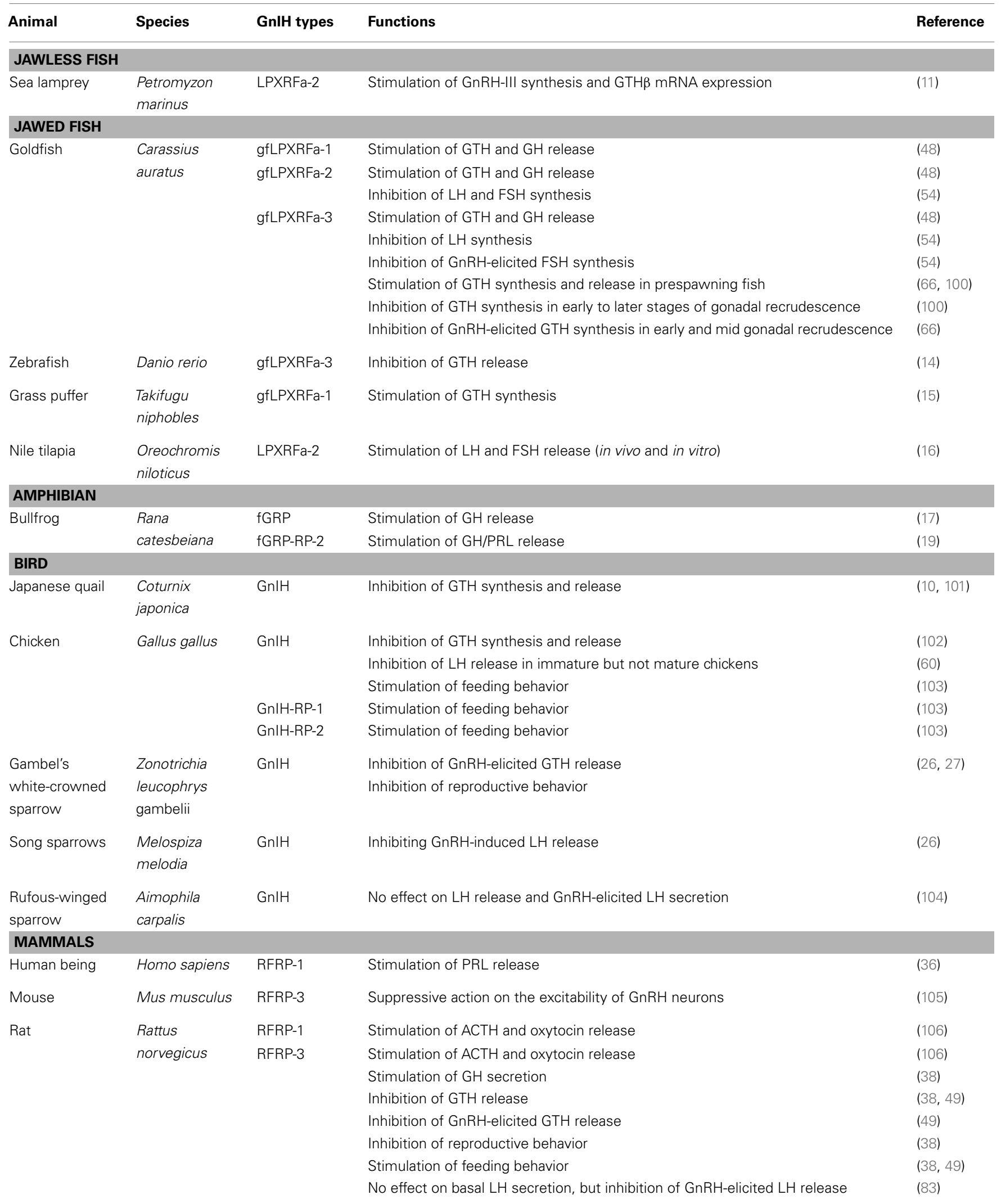


Table 3 | Continued

\begin{tabular}{llll}
\hline Animal & Species & GnIH types & Functions \\
\hline $\begin{array}{lll}\text { Syrian golden } \\
\text { hamster }\end{array}$ & $\begin{array}{l}\text { Mesocricetus } \\
\text { auratus }\end{array}$ & RFRP-1 & Inhibition of GTH release \\
Bovine & Bos taurus & RFRP-3 & Inhibition of GTH release \\
Ovine & Ovis aries & RFRP-3 & Inhibition of GnRH-elicited GTH release \\
& & Reduction of the amplitude of LH pulses
\end{tabular}

play a key role in the switch from mating and aggressive behaviors to those of parental care (114). Similarly, in the male quail, the role of GnIH in aggressive and sexual behaviors has been demonstrated (115), which has been suggested to be regulated by increasing neuroestrogen synthesis (110).

\section{Mammals}

In rats, GnIH injections suppress male sex behaviors (38). On the contrary, in a study in non-human primates, ewes, and rats, there is no effect of GnIH on sexual behavior (116), which could be due to different injection conditions (109). In the female Syrian hamsters, GnIH treatment inhibits sexual motivation and precopulatory behavior, but has no effect on copulatory behavior (117). $\mathrm{GnIH}$ is critical for the regulation of socio-sexual arousal, motivation, and performance in vertebrates (110). Therefore, changes in socio-sexual behaviors that are influenced by neuroestrogen levels can be modulated by $\mathrm{GnIH}$ in fish as in birds.

\section{REGULATORS OF GnIH SYSTEM}

In addition to the role of $\mathrm{GnIH}$, its regulatory mechanism has also been well examined $(52,85,118)$. For example, GnIH neurons express steroid receptors (ER $\alpha$ and $\mathrm{AR})$, which are responsible for steroid response in GnIH neurons (34, 119). There are numerous factors that suppress reproduction and these have been demonstrated as regulators of the GnIH system. GnIH system is known to be regulated by environmental cues particularly seasonal- and diurnal-rhythmicity (120-122). Furthermore, seasonal or photoperiod-dependent alterations of $\mathrm{GnIH}$ neurons indicate the modulatory role of melatonin in $\mathrm{GnIH}$ expression and synthesis (123).

\section{Seasonal regulation}

Jawless and jawed fish. Seasonal effect on GnIH orthologs has not been demonstrated in jawless fish species. In the goldfish, the effect of GnIH injections on the reduction of circulating LH levels is closely associated with seasonal dependent gonadal maturation stages (100). Interestingly, in the grass puffer, GnIH and $\mathrm{GnIH}$ receptor gene expression patterns are synchronized with diurnal and circadian rhythmicity, which indicates the involvement of GnIH system in the regulation of lunar-synchronized spawning (15). Furthermore, the potential neuronal mechanism of seasonaldependent change in GnIH system has been demonstrated (15). However, there is no direct evidence that demonstrates melatonin action on $\mathrm{GnIH}$ in fish, although the role of melatonin in the regulation of fish reproduction has been well recognized $(124,125)$. Nevertheless, in some teleosts species, there is direct projection from the pineal organ to the NPPv in the hypothalamus $(74,75)$, where GnIH neurons exist in teleost species. These results indicate that the $\mathrm{GnIH}$ system plays an important role to transmit photoperiodic cues via melatonin signaling in vertebrate reproduction.

Amphibians. In newts, peripheral treatment (intraperitoneal injection) of melatonin (at $1 \mathrm{~h}$ post-injection) or treatment in water containing melatonin (for 2 weeks) induces LPXRFa gene expression in the brain (21). Similarly, in bullfrogs, fGRP neurons in the $\mathrm{SCN}$ express $\mathrm{Mel}_{1 \mathrm{~b}}$, a melatonin receptor subtype (18). Furthermore, the expression of fGRP precursor mRNA is photoperiodically controlled, which increases under short-day photoperiods, when the nocturnal duration of melatonin secretion increases (18), suggesting stimulatory action of melatonin on fGRP secretion.

Birds. In the song sparrows, GnIH peptide levels are highest at the end of the breeding season (78). Similarly, in the Rufouswinged sparrow (A. carpalis), male birds during the breeding season have fewer, less densely labeled $\mathrm{GnIH}$ cell bodies than birds before the breeding season (80). While in the Australian zebra finches (Taeniopygia guttata), GnIH cell number and size, as well as GnIH mRNA levels are similar in the breeding and the nonbreeding conditions (126). In the Japanese quail, GnIH mRNA levels decrease significantly in the pinealectomized birds (127). Furthermore, melatonin administration causes a dose-dependent increase in the expression of GnIH precursor mRNA as well as the production and release of mature peptide, which is modulated via $\mathrm{Mel}_{1 \mathrm{c}}$ receptor subtype $(127,128)$. Interestingly, in the song birds, the pineal gland conveys photoperiodic information to the vocal control system to regulate song behavior (129). Furthermore, a recent study in female great tits (Parus major) has shown that melatonin treatment delays clutch initiation (130). Interestingly, one of the song-control nucleus in the telencephalic area, called area $\mathrm{X}$ is sensitive to melatonin (131) and GnIH neurons may have association with the area $\mathrm{X}(79)$. Therefore, it would be interesting to look into the possible association between $\mathrm{GnIH}$ system and song behavior.

Mammals. Similar to other vertebrates, mammalian $\mathrm{GnIH}$ is also influenced by seasonal change. In the sheep, lower expression of RFRP levels in the brain is concurrent with the breeding season (45). In Syrian and Siberian hamsters, RFRP mRNA and the number of RFRP-immunoreactive cell bodies decrease under short-day photoperiod (132). Furthermore, in the Syrian hamsters 


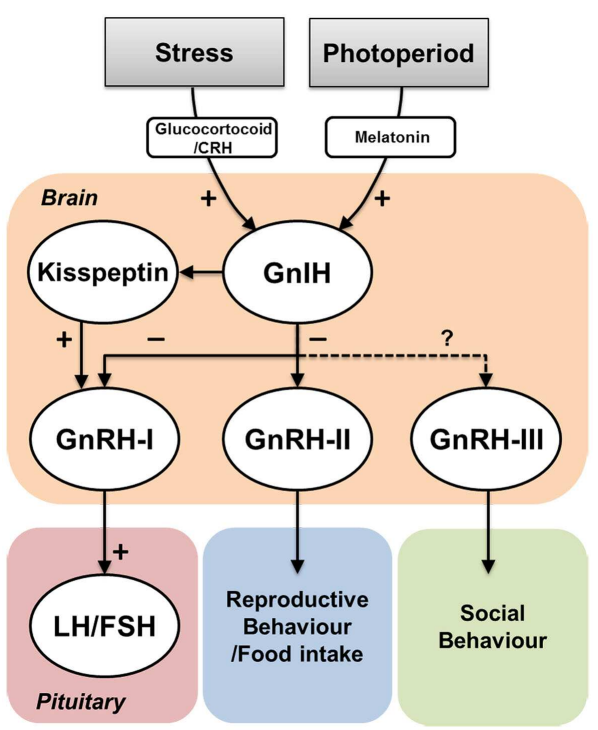

FIGURE 4 | Effect of environmental actions on GnlH system and its potential functions. Environmental cues such as social stress or seasonal/diurnal change influence on $\mathrm{GnlH}$ neurons via hormonal mediators such as corticosterone or melatonin. $\mathrm{GnlH}$ neurons negatively act on $\mathrm{GnRH}-\mathrm{I}$ and $\mathrm{GnRH}-\mathrm{II}$ neurons, which influence on gonadotropin ( $\mathrm{LH}$ and FSH) secretion in the pituitary and reproductive and/or food intake behaviors, respectively. In jawless and jawed fish, GnIH neurons send projection to $\mathrm{GnRH}-\mathrm{III}$ neurons, which may regulate social behaviors. In mammals, GnIH neurons are also closely associated with kisspeptin neurons. However, the role of $\mathrm{GnlH}$ in kisspeptin neurons remains unknown.

treated with melatonin (60 days), RFRP mRNA levels significantly decrease in the brain (132).

\section{Stress regulation}

$\mathrm{GnIH}$ has also been demonstrated as a modulator linking stress and reproduction in several vertebrate species. In addition, in birds and mammals, GnIH neurons are sensitive to stress hormones such as glucocorticoid or corticotropin-releasing hormone (CRH) (96, $133,134)$.

Jawless and jawed fish. There is no report demonstrating the involvement of $\mathrm{GnIH}$ in stress response in jawless and jawed fish. However, our promoter prediction search with the ALGGEN PROMO with TRANSFAC database v. $8.3(135,136)$ reveals the presence of a putative glucocorticoids response elements (GRE) at -983 bp upstream of the zebrafish GnIH gene promoter sequence. In addition, there are several putative GRE sites within $-2,000 \mathrm{bp}$ upstream of zebrafish GnIHR genes (GnIHR1: at $-1,755$ and $-1,976$ bp; GnIHR2: at $-30,-260,-265,-344,-1,642$, and $-1,942$ bp; GnRHR3: at -909 and $-1,294 \mathrm{bp})$. These results indicate that the role of $\mathrm{GnIH}$ signaling could be evolutionarily conserved in the vertebrates.

Birds. In the house sparrows (Passer domesticus), there is a significant increase in GnIH positive neurons in stressed birds (137). In the European starlings, plasma corticosterone concentration is positively correlated with GnIH mRNA abundance at the middle of the breeding season (114). In the Japanese quail, corticosterone treatment increases GnIH mRNA expression in the diencephalon (134). Furthermore, glucocorticoid receptor (GR) is expressed in quail GnIH neurons (134).

Mammals. In male rats, acute and chronic immobilization stress leads to an upregulation of GnIH gene expression (133). Furthermore, corticosterone treatment increased GnIH mRNA expression in a GnIH-expressing cell line, rHypoE-23, derived from the rat hypothalamus (138), which can be blocked by GR antagonist $(134,139)$. In male rats, $53 \%$ of GnIH neurons coexpress GR, and $11.8 \%$ of GnIH neurons co-express $\mathrm{CRH}$ receptor1 (133). Furthermore, one functional GRE has recently been identified in the promoter region of rat GnIH gene (134), suggesting that corticosterone directly induces $\mathrm{GnIH}$ transcription via GR.

\section{SUMMARY}

$\mathrm{GnIH}$ is an inhibitory hypothalamic RFamide neuropeptide that has been characterized in various vertebrates including in the fish species $(10,14,34,52,54)$. GnIH fibers and $\mathrm{GnIH}$ receptors are widely distributed in the brain as well as in the pituitary to regulate gonadotropin release $(10,34,59,81)$. GnIH fibers are also seen in close association with cells expressing other reproductive neuropeptides such as $\mathrm{GnRH}$ and kisspeptin neurons. $\mathrm{GnIH}$ and $\mathrm{GnIH}$ receptor signaling is also involved in several reproductive and non-reproductive functions, such as socio-sexual behaviors, appetite regulation, and stress response. Although the structure and function of the GnIH system is highly conserved in birds, mammals, and non-mammalian vertebrate species (Figure 4), there are still several questions that remain to be addressed in the case of fish $\mathrm{GnIH}$ because fish utilize a variety of reproductive strategies (140). For example, since the fish pituitary lacks the portal system of the ME and it is directly innervated by neurosecretory fibers (141), it would be interesting to know how GnIH acts on gonadotropes, whether directly or indirectly via other hypophysiotropic neurons such as GnRH neurons or the pineal gland. To understand the functional and physiological significance of vertebrate $\mathrm{GnIH}$, further studies of $\mathrm{GnIH}$ system in a variety of vertebrates in particular in fish species would be very important.

\section{AUTHOR CONTRIBUTIONS}

Satoshi Ogawa wrote the paper. Ishwar S. Parhar edited the paper.

\section{ACKNOWLEDGMENTS}

This work was supported by grants from the Malaysian Ministry of Higher Education, FRGS/2/2010/ST/MUSM/03/2 and FRGS/1/2013/SKK01/MUSM/03/2 (to Satoshi Ogawa), the Malaysian Ministry of Malaysian Ministry of Science, Technology, and Innovation, 02-02-10-SF0044 (to Ishwar S. Parhar), 0202-10-SF0161 (to Ishwar S. Parhar), and 02-02-10-SF0162 (to Satoshi Ogawa) and Monash University Malaysia, SO-10-01 (to Satoshi Ogawa), IP-09-01 (to Ishwar S. Parhar), and Neuroscience Research Strength grant (to Ishwar S. Parhar). 


\section{REFERENCES}

1. Belchetz P, Plant T, Nakai Y, Keogh E, Knobil E. Hypophysial responses to continuous and intermittent delivery of hypopthalamic gonadotropin-releasing hormone. Science (1978) 202:631-3. doi:10.1126/science.100883

2. Marshall JC, Kelch RP. Gonadotropin-releasing hormone: role of pulsatile secretion in the regulation of reproduction. N Engl J Med (1986) 315:1459-68. doi:10.1056/NEJM198612043152306

3. Schoech SJ, Rensel MA, Bridge ES, Boughton RK, Wilcoxen TE. Environment, glucocorticoids, and the timing of reproduction. Gen Comp Endocrinol (2009) 163:201-7. doi:10.1016/j.ygcen.2008.09.009

4. Tena-Sempere M. GPR54 and kisspeptin in reproduction. Hum Reprod Update (2006) 12:631-9. doi:10.1093/humupd/dml023

5. Roseweir AK, Millar RP. The role of kisspeptin in the control of gonadotrophin secretion. Hum Reprod Update (2009) 15:203-12. doi:10.1093/humupd/ dmn058

6. Irwig MS, Fraley GS, Smith JT, Acohido BV, Popa SM, Cunningham MJ, et al. Kisspeptin activation of gonadotropin releasing hormone neurons and regulation of KiSS-1 mRNA in the male rat. Neuroendocrinology (2004) 80:264-72. doi:10.1159/000083140

7. Clarkson J, Herbison AE. Postnatal development of kisspeptin neurons in mouse hypothalamus; sexual dimorphism and projections to gonadotropinreleasing hormone neurons. Endocrinology (2006) 147:5817-25. doi:10.1210/ en.2006-0787

8. Ramaswamy S, Guerriero KA, Gibbs RB, Plant TM. Structural interactions between kisspeptin and GnRH neurons in the mediobasal hypothalamus of the male rhesus monkey (Macaca mulatta) as revealed by double immunofluorescence and confocal microscopy. Endocrinology (2008) 149:4387-95. doi:10.1210/en.2008-0438

9. Parhar IS, Ogawa S, Sakuma Y. Laser-captured single digoxigenin-labeled neurons of gonadotropin-releasing hormone types reveal a novel $G$ proteincoupled receptor (Gpr54) during maturation in cichlid fish. Endocrinology (2004) 145:3613-8. doi:10.1210/en.2004-0395

10. Tsutsui K, Saigoh E, Ukena K, Teranishi H, Fujisawa Y, Kikuchi M, et al. A novel avian hypothalamic peptide inhibiting gonadotropin release. Biochem Biophys Res Commun (2000) 275:661-7. doi:10.1006/bbrc.2000.3350

11. Osugi T, Daukss D, Gazda K, Ubuka T, Kosugi T, Nozaki M, et al. Evolutionary origin of the structure and function of gonadotropin-inhibitory hormone: insights from lampreys. Endocrinology (2012) 153:2362-74. doi:10.1210/en. 2011-2046

12. Tsutsui K, Osugi T. Evolutionary origin and divergence of $\mathrm{GnIH}$ and its homologous peptides. Gen Comp Endocrinol (2009) 161:30-3. doi:10.1016/j.ygcen. 2008.10.002

13. Sawada K, Ukena K, Satake H, Iwakoshi E, Minakata H, Tsutsui K. Novel fish hypothalamic neuropeptide. Eur J Biochem (2002) 269:6000-8. doi:10.1046/j. 1432-1033.2002.03351.x

14. Zhang Y, Li S, Liu Y, Lu D, Chen H, Huang X, et al. Structural diversity of the gnih/gnih receptor system in teleost: its involvement in early development and the negative control of LH release. Peptides (2010) 31:1034-43. doi:10.1016/j.peptides.2010.03.003

15. Shahjahan M, Ikegami T, Osugi T, Ukena K, Doi H, Hattori A, et al. Synchronised expressions of LPXRFamide peptide and its receptor genes: seasonal, diurnal and circadian changes during spawning period in grass puffer. $\mathrm{J} \mathrm{Neu-}$ roendocrinol (2011) 23:39-51. doi:10.1111/j.1365-2826.2010.02081.x

16. Biran J, Golan M, Mizrahi N, Ogawa S, Parhar I, Sivan BL. LPXRFa, the piscine ortholog of $\mathrm{GnIH}$, and LPXRF receptor positively regulate gonadotropin secretion in tilapia (Oreochromis niloticus). Endocrinology (2014). doi:10.1210/en. 2013-2047

17. Koda A, Ukena K, Teranishi H, Ohta S, Yamamoto K, Kikuyama S, et al. A novel amphibian hypothalamic neuropeptide: isolation, localization, and biological activity. Endocrinology (2002) 143:411-9. doi:10.1210/endo.143.2.8630

18. Chowdhury VS, Yamamoto K, Saeki I, Hasunuma I, Shimura T, Tsutsui K. Melatonin stimulates the release of growth hormone and prolactin by a possible induction of the expression of frog growth hormone-releasing peptide and its related peptide- 2 in the amphibian hypothalamus. Endocrinology (2008) 149:962-70. doi:10.1210/en.2007-1427

19. Ukena K, Koda A, Yamamoto K, Kobayashi T, Iwakoshi-Ukena E, Minakata $\mathrm{H}$, et al. Novel neuropeptides related to frog growth hormone-releasing peptide: isolation, sequence, and functional analysis. Endocrinology (2003) 144:3879-84. doi:10.1210/en.2003-0359
20. Chartrel N, Dujardin C, Leprince J, Desrues L, Tonon MC, Cellier E, et al. Isolation, characterization, and distribution of a novel neuropeptide, Rana RFamide (R-RFa), in the brain of the European green frog Rana esculenta. J Comp Neurol (2002) 448:111-27. doi:10.1002/cne.10253

21. Chowdhury VS, Ubuka T, Osugi T, Shimura T, Tsutsui K. Identification, localization and expression of LPXRFamide peptides, and melatonin-dependent induction of their precursor mRNA in the newt brain. J Endocrinol (2011) 209:211-20. doi:10.1530/JOE-10-0494

22. Bentley GE, Kriegsfeld LJ, Osugi T, Ukena K, O’Brien S, Perfito $\mathrm{N}$, et al. Interactions of gonadotropin-releasing hormone $(\mathrm{GnRH})$ and gonadotropin-inhibitory hormone $(\mathrm{GnIH})$ in birds and mammals. J Exp Zool A Comp Exp Biol (2006) 305:807-14. doi:10.1002/jez.a.306

23. Bentley GE, Ubuka T, McGuire NL, Chowdhury VS, Morita Y, Yano T, et al. Gonadotropin-inhibitory hormone and its receptor in the avian reproductive system. Gen Comp Endocrinol (2008) 156:34-43. doi:10.1016/j.ygcen. 2007.10.003

24. Satake H, Hisada M, Kawada T, Minakata H, Ukena K, Tsutsui K. Characterization of a cDNA encoding a novel avian hypothalamic neuropeptide exerting an inhibitory effect on gonadotropin release. Biochem J (2001) 354:379-85. doi:10.1042/0264-6021:3540379

25. Ikemoto T, Park MK. Chicken RFamide-related peptide ( $\mathrm{GnIH})$ and two distinct receptor subtypes: identification, molecular characterization, and evolutionary considerations. J Reprod Dev (2005) 51:359-77. doi:10.1262/jrd.16087

26. Osugi T, Ukena K, Bentley GE, O’Brien S, Moore IT, Wingfield JC, et al. Gonadotropin-inhibitory hormone in Gambel's white-crowned sparrow (Zonotrichia leucophrys gambelii): cDNA identification, transcript localization and functional effects in laboratory and field experiments. J Endocrinol (2004) 182:33-42. doi:10.1677/joe.0.1820033

27. Bentley GE, Jensen JP, Kaur GJ, Wacker DW, Tsutsui K, Wingfield JC. Rapid inhibition of female sexual behavior by gonadotropin-inhibitory hormone $(\mathrm{GnIH})$. Horm Behav (2006) 49:550-5. doi:10.1016/j.yhbeh.2005.12.005

28. Ubuka T, Kim S, Huang YC, Reid J, Jiang J, Osugi T, et al. Gonadotropininhibitory hormone neurons interact directly with gonadotropin-releasing hormone-I and -II neurons in European starling brain. Endocrinology (2008) 149:268-78. doi:10.1210/en.2007-0983

29. Tobari Y, Iijima N, Tsunekawa K, Osugi T, Okanoya K, Tsutsui K, et al. Identification of gonadotropin-inhibitory hormone in the zebra finch (Taeniopygia guttata): peptide isolation, cDNA cloning and brain distribution. Peptides (2010) 31:816-26. doi:10.1016/j.peptides.2010.01.015

30. Ubuka T, Morgan K, Pawson AJ, Osugi T, Chowdhury VS, Minakata H, et al. Identification of human GnIH homologs, RFRP-1 and RFRP-3, and the cognate receptor, GPR147 in the human hypothalamic pituitary axis. PLoS One (2009) 4:e8400. doi:10.1371/journal.pone.0008400

31. Ubuka T, Lai H, Kitani M, Suzuuchi A, Pham V, Cadigan PA, et al. Gonadotropin-inhibitory hormone identification, cDNA cloning, and distribution in rhesus macaque brain. J Comp Neurol (2009) 517:841-55. doi:10.1002/cne.22191

32. Bentley GE, Tsutsui K, Kriegsfeld LJ. Recent studies of gonadotropin-inhibitory hormone $(\mathrm{GnIH})$ in the mammalian hypothalamus, pituitary and gonads. Brain Res (2010) 1364:62-71. doi:10.1016/j.brainres.2010.10.001

33. Smith JT, Shahab M, Pereira A, Pau K-YF, Clarke IJ. Hypothalamic expression of KISS1 and gonadotropin inhibitory hormone genes during the menstrual cycle of a non-human primate. Biol Reprod (2010) 83:568-77. doi:10.1095/biolreprod.110.085407

34. Kriegsfeld LJ, Mei DF, Bentley GE, Ubuka T, Mason AO, Inoue K, et al. Identification and characterization of a gonadotropin-inhibitory system in the brains of mammals. Proc Natl Acad Sci U S A (2006) 103:2410-5. doi:10.1073/pnas.0511003103

35. Poling MC, Quennell JH, Anderson GM, Kauffman AS. Kisspeptin neurones do not directly signal to RFRP-3 neurones but RFRP-3 may directly modulate a subset of hypothalamic kisspeptin cells in mice. J Neuroendocrinol (2013) 25:876-86. doi:10.1111/jne.12084

36. Hinuma S, Shintani Y, Fukusumi S, Iijima N, Matsumoto Y, Hosoya M, et al. New neuropeptides containing carboxy-terminal RFamide and their receptor in mammals. Nat Cell Biol (2000) 2:703-8. doi:10.1038/35036326

37. Ukena K, Iwakoshi E, Minakata H, Tsutsui K. A novel rat hypothalamic RFamide-related peptide identified by immunoaffinity chromatography and mass spectrometry. FEBS Lett (2002) 512:255-8. doi:10.1016/S0014-5793(02) 02275-5 
38. Johnson MA, Tsutsui K, Fraley GS. Rat RFamide-related peptide-3 stimulates GH secretion, inhibits LH secretion, and has variable effects on sex behavior in the adult male rat. Horm Behav (2007) 51:171-80. doi:10.1016/j.yhbeh.2006. 09.009

39. Rizwan M, Harbid A, Inglis M, Quennell J, Anderson G. Evidence that hypothalamic RFamide related peptide-3 neurones are not leptin-responsive in mice and rats. J Neuroendocrinol (2014) 26:247-57. doi:10.1111/jne.12140

40. Ubuka T, Inoue K, Fukuda Y, Mizuno T, Ukena K, Kriegsfeld LJ, et al. Identification, expression, and physiological functions of Siberian hamster gonadotropin-inhibitory hormone. Endocrinology (2012) 153:373-85. doi:10. 1210/en.2011-1110

41. Fukusumi S, Habata Y, Yoshida H, Iijima N, Kawamata Y, Hosoya M, et al. Characteristics and distribution of endogenous RFamide-related peptide1. Biochim Biophys Acta (2001) 1540:221-32. doi:10.1016/S0167-4889(01) 00135-5

42. Yoshida H, Habata Y, Hosoya M, Kawamata Y, Kitada C, Hinuma S. Molecular properties of endogenous RFamide-related peptide-3 and its interaction with receptors. Biochim Biophys Acta (2003) 1593:151-7. doi:10.1016/S01674889(02)00389-0

43. Clarke IJ, Sari IP, Qi Y, Smith JT, Parkington HC, Ubuka T, et al. Potent action of RFamide-related peptide- 3 on pituitary gonadotropes indicative of a hypophysiotropic role in the negative regulation of gonadotropin secretion. Endocrinology (2008) 149:5811-21. doi:10.1210/en.2008-0575

44. Dardente H, Birnie M, Lincoln GA, Hazlerigg DG. RFamide-Related peptide and its cognate receptor in the sheep: cDNA cloning, mRNA distribution in the hypothalamus and the effect of photoperiod. J Neuroendocrinol (2008) 20:1252-9. doi:10.1111/j.1365-2826.2008.01784.x

45. Smith JT, Coolen LM, Kriegsfeld LJ, Sari IP, Jaafarzadehshirazi MR, Maltby M, et al. Variation in kisspeptin and RFamide-related peptide (RFRP) expression and terminal connections to gonadotropin-releasing hormone neurons in the brain: a novel medium for seasonal breeding in the sheep. Endocrinology (2008) 149:5770-82. doi:10.1210/en.2008-0581

46. Qi Y, Oldfield BJ, Clarke IJ. Projections of RFamide-related peptide-3 neurones in the ovine hypothalamus, with special reference to regions regulating energy balance and reproduction. J Neuroendocrinol (2009) 21:690-7. doi:10.1111/j.1365-2826.2009.01886.x

47. Li X, Su J, Lei Z, Zhao Y, Jin M, Fang R, et al. Gonadotropin-inhibitory hormone $(\mathrm{GnIH})$ and its receptor in the female pig: cDNA cloning, expression in tissues and expression pattern in the reproductive axis during the estrous cycle. Peptides (2012) 36:176-85. doi:10.1016/j.peptides.2012.05.008

48. Amano M, Moriyama S, Iigo M, Kitamura S, Amiya N, Yamamori K, et al. Novel fish hypothalamic neuropeptides stimulate the release of gonadotrophins and growth hormone from the pituitary of sockeye salmon. J Endocrinol (2006) 188:417-23. doi:10.1677/joe.1.06494

49. Murakami M, Matsuzaki T, Iwasa T, Yasui T, Irahara M, Osugi T, et al. Hypophysiotropic role of RFamide-related peptide- 3 in the inhibition of $\mathrm{LH}$ secretion in female rats. J Endocrinol (2008) 199:105-12. doi:10.1677/JOE-080197

50. Kadokawa H, Shibata M, Tanaka Y, Kojima T, Matsumoto K, Oshima K, et al. Bovine C-terminal octapeptide of RFamide-related peptide-3 suppresses luteinizing hormone $(\mathrm{LH})$ secretion from the pituitary as well as pulsatile $\mathrm{LH}$ secretion in bovines. Domest Anim Endocrinol (2009) 36:219-24. doi:10.1016/ j.domaniend.2009.02.001

51. Ubuka T, McGuire NL, Calisi RM, Perfito N, Bentley GE. The control of reproductive physiology and behavior by gonadotropin-inhibitory hormone. Integr Comp Biol (2008) 48:560-9. doi:10.1093/icb/icn019

52. Tsutsui K, Ubuka T, Bentley GE, Kriegsfeld LJ. Gonadotropin-inhibitory hormone (GnIH): discovery, progress and prospect. Gen Comp Endocrinol (2012) 177:305-14. doi:10.1016/j.ygcen.2012.02.013

53. Tsutsui K, Bentley GE, Kriegsfeld LJ, Osugi T, Seong JY, Vaudry H. Discovery and evolutionary history of gonadotrophin-inhibitory hormone and kisspeptin: new key neuropeptides controlling reproduction. J Neuroendocrinol (2010) 22:716-27. doi:10.1111/j.1365-2826.2010.02018.x

54. Qi X, Zhou W, Li S, Lu D, Yi S, Xie R, et al. Evidences for the regulation of GnRH and GTH expression by GnIH in the goldfish, Carassius auratus. Mol Cell Endocrinol (2013) 366:9-20. doi:10.1016/j.mce.2012.11.001

55. Qi X, Zhou W, Lu D, Wang Q, Zhang H, Li S, et al. Sexual dimorphism of steroidogenesis regulated by $\mathrm{GnIH}$ in the goldfish, Carassius auratus. Biol Reprod (2013) 88(89):81-7. doi:10.1095/biolreprod.112.105114
56. Berthelot C, Brunet F, Chalopin D, Juanchich A, Bernard M, Noel B, et al. The rainbow trout genome provides novel insights into evolution after wholegenome duplication in vertebrates. Nat Commun (2014) 5:3657. doi:10.1038/ ncomms 4657

57. Klein SL, Strausberg RL, Wagner L, Pontius J, Clifton SW, Richardson P. Genetic and genomic tools for Xenopus research: the NIH Xenopus initiative. Dev Dyn (2002) 225:384-91. doi:10.1002/dvdy.10174

58. Vonk FJ, Casewell NR, Henkel CV, Heimberg AM, Jansen HJ, McCleary RJ, et al. The king cobra genome reveals dynamic gene evolution and adaptation in the snake venom system. Proc Natl Acad Sci U S A (2013) 110:20651-6. doi:10.1073/pnas.1314702110

59. Yin H, Ukena K, Ubuka T, Tsutsui K. A novel G protein-coupled receptor for gonadotropin-inhibitory hormone in the Japanese quail (Coturnix japonica): identification, expression and binding activity. J Endocrinol (2005) 184:257-66. doi:10.1677/joe.1.05926

60. Maddineni SR, Ocón-Grove OM, Krzysik-Walker SM, Hendricks GL, Ramachandran R. Gonadotropin-inhibitory hormone $(\mathrm{GnIH})$ receptor gene is expressed in the chicken ovary: potential role of $\mathrm{GnIH}$ in follicular maturation. Reproduction (2008) 135:267-74. doi:10.1530/REP-07-0369

61. Shimizu M, Bédécarrats GY. Activation of the chicken gonadotropin-inhibitory hormone receptor reduces gonadotropin releasing hormone receptor signaling. Gen Comp Endocrinol (2010) 167:331-7. doi:10.1016/j.ygcen.2010.03.029

62. Vassilatis DK, Hohmann JG, Zeng H, Li F, Ranchalis JE, Mortrud MT, et al. The $G$ protein-coupled receptor repertoires of human and mouse. Proc Natl Acad Sci U S A (2003) 100:4903-8. doi:10.1073/pnas.0230374100

63. Soga T, Wong DW, Clarke IJ, Parhar IS. Citalopram (antidepressant) administration causes sexual dysfunction in male mice through RF-amide related peptide in the dorsomedial hypothalamus. Neuropharmacology (2010) 59:77-85. doi:10.1016/j.neuropharm.2010.03.018

64. Gibson EM, Humber SA, Jain S, Williams WP III, Zhao S, Bentley GE, et al. Alterations in RFamide-related peptide expression are coordinated with the preovulatory luteinizing hormone surge. Endocrinology (2008) 149:4958-69. doi:10.1210/en.2008-0316

65. Zhao S, Zhu E, Yang C, Bentley GE, Tsutsui K, Kriegsfeld LJ. RFamiderelated peptide and messenger ribonucleic acid expression in mammalian testis: association with the spermatogenic cycle. Endocrinology (2010) 151:617-27. doi:10.1210/en.2009-0978

66. Moussavi M, Wlasichuk M, Chang JP, Habibi HR. Seasonal effect of gonadotrophin inhibitory hormone on gonadotrophin-releasing hormoneinduced gonadotroph functions in the goldfish pituitary. J Neuroendocrinol (2013) 25:506-16. doi:10.1111/jne.12024

67. Bonini JA, Jones KA, Adham N, Forray C, Artymyshyn R, Durkin MM, et al. Identification and characterization of two $\mathrm{G}$ protein-coupled receptors for neuropeptide FF. J Biol Chem (2000) 275:39324-31. doi:10.1074/jbc.M004385200

68. Liu Q, Guan X-M, Martin WJ, McDonald TP, Clements MK, Jiang Q, et al. Identification and characterization of novel mammalian neuropeptide FF-like peptides that attenuate morphine-induced antinociception. J Biol Chem (2001) 276:36961-9. doi:10.1074/jbc.M105308200

69. Ubuka T, Son YL, Bentley GE, Millar RP, Tsutsui K. Gonadotropin-inhibitory hormone $(\mathrm{GnIH}), \mathrm{GnIH}$ receptor and cell signaling. Gen Comp Endocrinol (2013) 190:10-7. doi:10.1016/j.ygcen.2013.02.030

70. Gouarderes C, Mazarguil H, Mollereau C, Chartrel N, Leprince J, Vaudry $\mathrm{H}$, et al. Functional differences between NPFF1 and NPFF2 receptor coupling: high intrinsic activities of RFamide-related peptides on stimulation of [35S] GTPgammaS binding. Neuropharmacology (2007) 52:376-86. doi:10. 1016/j.neuropharm.2006.07.034

71. Tsutsui K, Ukena K. Hypothalamic LPXRF-amide peptides in vertebrates: identification, localization and hypophysiotropic activity. Peptides (2006) 27:1121-9. doi:10.1016/j.peptides.2005.06.036

72. Biswas S, Jadhao AG, Pinelli C, Palande NV, Tsutsui K. GnIH and GnRH expressions in the central nervous system and pituitary of Indian major carp, Labeo rohita during ontogeny: an immunocytochemical study. Gen Comp Endocrinol (2014). doi:10.1016/j.ygcen.2014.06.005

73. Stewart AJ, Katz AA, Millar RP, Morgan K. Retention and silencing of preproGnRH-II and type II GnRH receptor genes in mammals. Neuroendocrinology (2009) 90:416-32. doi:10.1159/000233303

74. Ekström P, van Veen T. Central connections of the pineal organ in the threespined stickleback, Gasterosteus aculeatus L (Teleostei). Cell Tissue Res (1983) 232:141-55. doi:10.1007/BF00222380 
75. Ekström P, van Veen T. Pineal neural connections with the brain in two teleosts, the crucian carp and the European eel. J Pineal Res (1984) 1:245-61. doi:10.1111/j.1600-079X.1984.tb00216.x

76. Puzdrowski RL, Northcutt RG. Central projections of the pineal complex in the silver lamprey Ichthyomyzon unicuspis. Cell Tissue Res (1989) 255:269-74. doi:10.1007/BF00224108

77. Kawano E, Takahata Y, Oishi T, Ukena K, Tsutsui K, Tamotsu S. Neural interaction of gonadotropin-regulating hormone immunoreactive neurons and the suprachiasmatic nucleus with the paraventricular organ in the Japanese grass lizard (Takydromus tachydromoides). Zoolog Sci (2006) 23:277-87. doi:10.2108/zsj.23.277

78. Bentley GE, Perfito N, Ukena K, Tsutsui K, Wingfield JC. Gonadotropininhibitory peptide in song sparrows (Melospiza melodia) in different reproductive conditions, and in house sparrows (Passer domesticus) relative to chickengonadotropin-releasing hormone. J Neuroendocrinol (2003) 15:794-802. doi: 10.1046/j.1365-2826.2003.01062.x

79. Ukena K, Ubuka T, Tsutsui K. Distribution of a novel avian gonadotropininhibitory hormone in the quail brain. Cell Tissue Res (2003) 312:73-9. doi:10.1007/s00441-003-0700-x

80. Small TW, Sharp PJ, Bentley GE, Millar RP, Tsutsui K, Mura E, et al. Photoperiod-independent hypothalamic regulation of luteinizing hormone secretion in a free-living sonoran desert bird, the rufous-winged sparrow (Aimophila carpalis). Brain Behav Evol (2008) 71:127-42. doi:10.1159/ 000111459

81. Soga T, Kitahashi T, Clarke IJ, Parhar IS. Gonadotropin-inhibitory hormone promoter-driven enhanced green fluorescent protein expression decreases during aging in female rats. Endocrinology (2014) 155:1944-55. doi:10.1210/en. 2013-1786

82. Smith JT, Ross Young I, Veldhuis JD, Clarke IJ. Gonadotropin-inhibitory hormone $(\mathrm{GnIH})$ secretion into the ovine hypophyseal portal system. Endocrinology (2012) 153:3368-75. doi:10.1210/en.2012-1088

83. Rizwan MZ, Porteous R, Herbison AE, Anderson GM. Cells expressing RFamide-related peptide-1/3, the mammalian gonadotropin-inhibitory hormone orthologs, are not hypophysiotropic neuroendocrine neurons in the rat. Endocrinology (2009) 150:1413-20. doi:10.1210/en.2008-1287

84. Iwasa T, Matsuzaki T, Murakami M, Kinouchi R, Osugi T, Gereltsetseg G, et al. Developmental changes in the mammalian gonadotropin-inhibitory hormone (GnIH) ortholog RFamide-related peptide (RFRP) and its cognate receptor GPR147 in the rat hypothalamus. Int J Dev Neurosci (2012) 30:31-7. doi:10.1016/j.ijdevneu.2011.10.003

85. Ubuka T, Son YL, Tobari Y, Narihiro M, Bentley GE, Kriegsfeld LJ, et al. Central and direct regulation of testicular activity by gonadotropin-inhibitory hormone and its receptor. Front Endocrinol (Lausanne) (2014) 5:8. doi:10.3389/ fendo.2014.00008

86. Tsutsui K, Bentley GE, Bedecarrats G, Osugi T, Ubuka T, Kriegsfeld LJ. Gonadotropin-inhibitory hormone $(\mathrm{GnIH})$ and its control of central and peripheral reproductive function. Front Neuroendocrinol (2010) 31:284-95. doi:10.1016/j.yfrne.2010.03.001

87. Singh P, Krishna A, Sridaran R, Tsutsui K. Changes in GnRH I, bradykinin and their receptors and GnIH in the ovary of Calotes versicolor during reproductive cycle. Gen Comp Endocrinol (2008) 159:158-69. doi:10.1016/j.ygcen. 2008.08.016

88. McGuire NL, Bentley GE. A functional neuropeptide system in vertebrate gonads: gonadotropin-inhibitory hormone and its receptor in testes of fieldcaught house sparrow (Passer domesticus). Gen Comp Endocrinol (2010) 166:565-72. doi:10.1016/j.ygcen.2010.01.010

89. McGuire NL, Kangas K, Bentley GE. Effects of melatonin on peripheral reproductive function: regulation of testicular $\mathrm{GnIH}$ and testosterone. Endocrinology (2011) 152:3461-70. doi:10.1210/en.2011-1053

90. Singh P, Krishna A, Sridaran R, Tsutsui K. Immunohistochemical localization of $\mathrm{GnRH}$ and RFamide-related peptide- 3 in the ovaries of mice during the estrous cycle. J Mol Histol (2011) 42:371-81. doi:10.1007/s10735-011-9340-8

91. Oishi H, Klausen C, Bentley GE, Osugi T, Tsutsui K, Gilks CB, et al. The human gonadotropin-inhibitory hormone ortholog RFamide-related peptide-3 suppresses gonadotropin-induced progesterone production in human granulosa cells. Endocrinology (2012) 153:3435-45. doi:10.1210/en.2012-1066

92. Anjum S, Tsutsui K. Inhibitory roles of the mammalian GnIH ortholog RFRP3 in testicular activities in adult mice. J Endocrinol (2014) 223(1):79-91. doi:10.1530/JOE-14-0333
93. Singh P, Krishna A, Tsutsui K. Effects of gonadotropin-inhibitory hormone on folliculogenesis and steroidogenesis of cyclic mice. Fertil Steril (2011) 95:1397-404. doi:10.1016/j.fertnstert.2010.03.052

94. Poling MC, Kim J, Dhamija S, Kauffman AS. Development, sex steroid regulation, and phenotypic characterization of RFamide-related peptide (Rfrp) gene expression and RFamide receptors in the mouse hypothalamus. Endocrinology (2012) 153:1827-40. doi:10.1210/en.2011-2049

95. Rizwan MZ, Poling MC, Corr M, Cornes PA, Augustine RA, Quennell JH, et al. RFamide-related peptide-3 receptor gene expression in $\mathrm{GnRH}$ and kisspeptin neurons and GnRH-dependent mechanism of action. Endocrinology (2012) 153:3770-9. doi:10.1210/en.2012-1133

96. Soga T, Dalpatadu S, Wong D, Parhar I. Neonatal dexamethasone exposure down-regulates $\mathrm{GnRH}$ expression through the $\mathrm{GnIH}$ pathway in female mice. Neuroscience (2012) 218:56-64. doi:10.1016/j.neuroscience.2012.05.023

97. Umatani C, Abe H, Oka Y. Neuropeptide RFRP inhibits the pacemaker activity of terminal nerve GnRH neurons. J Neurophysiol (2013) 109:2354-63. doi:10.1152/jn.00712.2012

98. Fu L-Y, van den Pol AN. Kisspeptin directly excites anorexigenic proopiomelanocortin neurons but inhibits orexigenic neuropeptide Y cells by an indirect synaptic mechanism. J Neurosci (2010) 30:10205-19. doi:10.1523/ JNEUROSCI.2098-10.2010

99. Wu M, Dumalska I, Morozova E, Van Den Pol AN, Alreja M. Gonadotropin inhibitory hormone inhibits basal forebrain vGluT2-gonadotropin-releasing hormone neurons via a direct postsynaptic mechanism. J Physiol (2009) 587:1401-11. doi:10.1113/jphysiol.2008.166447

100. Moussavi M, Wlasichuk M, Chang JP, Habibi HR. Seasonal effect of GnIH on gonadotrope functions in the pituitary of goldfish. Mol Cell Endocrinol (2012) 350:53-60. doi:10.1016/j.mce.2011.11.020

101. Ubuka T, Ukena K, Sharp PJ, Bentley GE, Tsutsui K. Gonadotropin-inhibitory hormone inhibits gonadal development and maintenance by decreasing gonadotropin synthesis and release in male quail. Endocrinology (2006) 147:1187-94. doi:10.1210/en.2005-1178

102. Ciccone N, Dunn I, Boswell T, Tsutsui K, Ubuka T, Ukena K, et al. Gonadotrophin inhibitory hormone depresses gonadotrophin $\alpha$ and folliclestimulating hormone $\beta$ subunit expression in the pituitary of the domestic chicken. J Neuroendocrinol (2004) 16:999-1006. doi:10.1111/j.1365-2826. 2005.01260.x

103. Tachibana T, Sato M, Takahashi H, Ukena K, Tsutsui K, Furuse $M$. Gonadotropin-inhibiting hormone stimulates feeding behavior in chicks. Brain Res (2005) 1050:94-100. doi:10.1016/j.brainres.2005.05.035

104. Deviche P, Small T, Sharp P, Tsutsui K. Control of luteinizing hormone and testosterone secretion in a flexibly breeding male passerine, the rufouswinged sparrow, Aimophila carpalis. Gen Comp Endocrinol (2006) 149:226-35. doi:10.1016/j.ygcen.2006.06.004

105. Ducret E, Anderson GM, Herbison AE. RFamide-related peptide-3 (RFRP3), a mammalian gonadotropin-inhibitory hormone ortholog, regulates gonadotropin-releasing hormone $(\mathrm{GnRH})$ neuron firing in the mouse. Endocrinology (2009) 150(6):2799-804. doi:10.1210/en.2008-1623

106. Kaewwongse M, Takayanagi Y, Onaka T. Effects of RFamide-related peptide (RFRP)-1 and RFRP-3 on oxytocin release and anxiety-related behaviour in rats. J Neuroendocrinol (2011) 23:20-7. doi:10.1111/j.1365-2826.2010. 02077.x

107. Sari IP, Rao A, Smith JT, Tilbrook AJ, Clarke IJ. Effect of RF-amide-related peptide- 3 on luteinizing hormone and follicle-stimulating hormone synthesis and secretion in ovine pituitary gonadotropes. Endocrinology (2009) 150:5549-56. doi:10.1210/en.2009-0775

108. Pineda R, Garcia-Galiano D, Sanchez-Garrido MA, Romero M, Ruiz-Pino F, Aguilar E, et al. Characterization of the inhibitory roles of RFRP3, the mammalian ortholog of $\mathrm{GnIH}$, in the control of gonadotropin secretion in the rat: in vivo and in vitro studies. Am J Physiol Endocrinol Metab (2010) 299:E39-46. doi:10.1152/ajpendo.00108.2010

109. Calisi RM. An integrative overview of the role of gonadotropin-inhibitory hormone in behavior: applying Tinbergen's four questions. Gen Comp Endocrinol (2014) 203:95-105. doi:10.1016/j.ygcen.2014.03.028

110. Ubuka T, Haraguchi S, Tobari Y, Narihiro M, Ishikawa K, Hayashi T, et al. Hypothalamic inhibition of socio-sexual behaviour by increasing neuroestrogen synthesis. Nat Commun (2014) 5:3061. doi:10.1038/ncomms4061

111. Black MP, Balthazart J, Baillien M, Grober MS. Socially induced and rapid increases in aggression are inversely related to brain aromatase activity in 
a sex-changing fish, Lythrypnus dalli. Proc Biol Sci (2005) 272:2435-40. doi:10.1098/rspb.2005.3210

112. Hallgren SL, Linderoth M, Olsén KH. Inhibition of cytochrome $\mathrm{p} 450$ brain aromatase reduces two male specific sexual behaviours in the male Endler guppy (Poecilia reticulata). Gen Comp Endocrinol (2006) 147:323-8. doi:10.1016/j. ygcen.2006.02.005

113. Huffman LS, O'Connell LA, Hofmann HA. Aromatase regulates aggression in the African cichlid fish Astatotilapia burtoni. Physiol Behav (2013) 11(2113):77-83. doi:10.1016/j.physbeh.2013.02.004

114. Calisi RM, Díaz-Muñoz SL, Wingfield JC, Bentley GE. Social and breeding status are associated with the expression of GnIH. Genes Brain Behav (2011) 10:557-64. doi:10.1111/j.1601-183X.2011.00693.x

115. Ubuka T, Mizuno T, Fukuda Y, Bentley GE, Wingfield JC, Tsutsui K. RNA interference of gonadotropin-inhibitory hormone gene induces aggressive and sexual behaviors in birds. Gen Comp Endocrinol (2013) 181:179-86. doi:10.1016/j.ygcen.2012.09.010

116. Clarke IJ, Smith JT, Henry BA, Oldfield BJ, Stefanidis A, Millar RP, et al. Gonadotropin-inhibitory hormone is a hypothalamic peptide that provides a molecular switch between reproduction and feeding. Neuroendocrinology (2012) 95:305-16. doi:10.1159/000332822

117. Piekarski DJ, Zhao S, Jennings KJ, Iwasa T, Legan SJ, Mikkelsen JD, et al. Gonadotropin-inhibitory hormone reduces sexual motivation but not lordosis behavior in female Syrian hamsters (Mesocricetus auratus). Horm Behav (2013) 64:501-10. doi:10.1016/j.yhbeh.2013.06.006

118. Tsutsui K, Ubuka T, Yin H, Osugi T, Ukena K, Bentley GE, et al. Mode of action and functional significance of avian gonadotropin-inhibitory hormone (GnIH): a review. J Exp Zool A Comp Exp Biol (2006) 305:801-6. doi:10.1002/jez.a.305

119. Molnar C, Kallo I, Liposits Z, Hrabovszky E. Estradiol down-regulates RF-amide-related peptide (RFRP) expression in the mouse hypothalamus. Endocrinology (2011) 152:1684-90. doi:10.1210/en.2010-1418

120. Greives TJ, Kriegsfeld LJ, Bentley GE, Tsutsui K, Demas GE. Recent advances in reproductive neuroendocrinology: a role for RFamide peptides in seasonal reproduction? Proc Biol Sci (2008) 275:1943-51. doi:10.1098/rspb.2008.0433

121. Smith J. The role of kisspeptin and gonadotropin inhibitory hormone in the seasonal regulation of reproduction in sheep. Domest Anim Endocrinol (2012) 43:75-84. doi:10.1016/j.domaniend.2011.11.003

122. Tsutsui K, Ubuka T, Bentley GE, Kriegsfeld LJ. Review: regulatory mechanisms of gonadotropin-inhibitory hormone $(\mathrm{GnIH})$ synthesis and release in photoperiodic animals. Front Neurosci (2013) 7:60. doi:10.3389/fnins.2013.00060

123. Chowdhury VS, Ubuka T, Tsutsui K. Review: melatonin stimulates the synthesis and release of gonadotropin-inhibitory hormone in birds. Gen Comp Endocrinol (2013) 181:175-8. doi:10.1016/j.ygcen.2012.08.005

124. Bromage N, Porter M, Randall C. The environmental regulation of maturation in farmed finfish with special reference to the role of photoperiod and melatonin. Aquaculture (2001) 197:63-98. doi:10.1016/S0044-8486(01)00583-X

125. Falcón J, Migaud H, Muñoz-Cueto JA, Carrillo M. Current knowledge on the melatonin system in teleost fish. Gen Comp Endocrinol (2010) 165:469-82. doi:10.1016/j.ygcen.2009.04.026

126. Perfito N, Zann R, Ubuka T, Bentley G, Hau M. Potential roles for GNIH and GNRH-II in reproductive axis regulation of an opportunistically breeding songbird. Gen Comp Endocrinol (2011) 173:20-6. doi:10.1016/j.ygcen.2011.04. 016

127. Ubuka T, Bentley GE, Ukena K, Wingfield JC, Tsutsui K. Melatonin induces the expression of gonadotropin-inhibitory hormone in the avian brain. Proc Natl Acad Sci U S A (2005) 102:3052-7. doi:10.1073/pnas.0403840102

128. Chowdhury VS, Yamamoto K, Ubuka T, Bentley GE, Hattori A, Tsutsui K. Melatonin stimulates the release of gonadotropin-inhibitory hormone by the avian hypothalamus. Endocrinology (2010) 151:271-80. doi:10.1210/en.2009-0908

129. Wang G, Harpole CE, Paulose J, Cassone VM. The role of the pineal gland in the photoperiodic control of bird song frequency and repertoire in the house sparrow, Passer domesticus. Horm Behav (2014) 65:372-9. doi:10.1016/j.yhbeh. 2014.02.008

130. Greives TJ, Kingma SA, Beltrami G, Hau M. Melatonin delays clutch initiation in a wild songbird. Biol Lett (2012) 8:330-2. doi:10.1098/rsbl.2011.1100

131. Bentley GE, Van't Hof TJ, Ball GF. Seasonal neuroplasticity in the songbird telencephalon: a role for melatonin. Proc Natl Acad Sci U S A (1999) 96:4674-9. doi:10.1073/pnas.96.8.4674

132. Revel FG, Saboureau M, Pevet P, Simonneaux V, Mikkelsen JD. RFamide-related peptide gene is a melatonin-driven photoperiodic gene. Endocrinology (2008) 149:902-12. doi:10.1210/en.2007-0848

133. Kirby ED, Geraghty AC, Ubuka T, Bentley GE, Kaufer D. Stress increases putative gonadotropin inhibitory hormone and decreases luteinizing hormone in male rats. Proc Natl Acad Sci U S A (2009) 106:11324-9. doi:10.1073/pnas. 0901176106

134. Son YL, Ubuka T, Narihiro M, Fukuda Y, Hasunuma I, Yamamoto K, et al. Molecular basis for the activation of gonadotropin-inhibitory hormone gene transcription by corticosterone. Endocrinology (2014) 155:1817-26. doi:10.1210/ en.2013-2076

135. Messeguer X, Escudero R, Farré D, Núñez O, Martinez J, Albà MM. PROMO: detection of known transcription regulatory elements using speciestailored searches. Bioinformatics (2002) 18:333-4. doi:10.1093/bioinformatics/ 18.2.333

136. Farré D, Roset R, Huerta M, Adsuara JE, Roselló L, Albà MM, et al. Identification of patterns in biological sequences at the ALGGEN server: PROMO and MALGEN. Nucleic Acids Res (2003) 31:3651-3. doi:10.1093/nar/gkg605

137. Calisi RM, Rizzo NO, Bentley GE. Seasonal differences in hypothalamic EGR1 and $\mathrm{GnIH}$ expression following capture-handling stress in house sparrows (Passer domesticus). Gen Comp Endocrinol (2008) 157:283-7. doi:10.1016/j. ygcen.2008.05.010

138. Gingerich S, Wang X, Lee P, Dhillon S, Chalmers J, Koletar M, et al. The generation of an array of clonal, immortalized cell models from the rat hypothalamus: analysis of melatonin effects on kisspeptin and gonadotropin-inhibitory hormone neurons. Neuroscience (2009) 162:1134-40. doi:10.1016/j.neuroscience. 2009.05.026

139. Gojska NM, Belsham DD. Glucocorticoid receptor-mediated regulation of Rfrp (GnIH) and Gprl47 (GnIH-R) synthesis in immortalized hypothalamic neurons. Mol Cell Endocrinol (2014) 384:23-31. doi:10.1016/j.mce.2013.12.015

140. Kime DE. A strategy for assessing the effects of xenobiotics on fish reproduction. Sci Total Environ (1999) 225:3-11. doi:10.1016/S0048-9697(98)00328-3

141. Peter RE, Yu KL, Marchant TA, Rosenblum PM. Direct neural regulation of the teleost adenohypophysis. J Exp Zool (1990) 256:84-9. doi:10.1002/jez. 1402560415

Conflict of Interest Statement: The authors declare that the research was conducted in the absence of any commercial or financial relationships that could be construed as a potential conflict of interest.

Received: 31 July 2014; paper pending published: 29 August 2014; accepted: 06 October 2014; published online: 24 October 2014.

Citation: Ogawa S and Parhar IS (2014) Structural and functional divergence of gonadotropin-inhibitory hormone from jawless fish to mammals. Front. Endocrinol. 5:177. doi:10.3389/fendo.2014.00177

This article was submitted to Neuroendocrine Science, a section of the journal Frontiers in Endocrinology.

Copyright $(2014$ Ogawa and Parhar. This is an open-access article distributed under the terms of the Creative Commons Attribution License (CC BY). The use, distribution or reproduction in other forums is permitted, provided the original author(s) or licensor are credited and that the original publication in this journal is cited, in accordance with accepted academic practice. No use, distribution or reproduction is permitted which does not comply with these terms. 